\title{
Wild food plants and fungi sold in the markets of Luang Prabang, Lao PDR
}

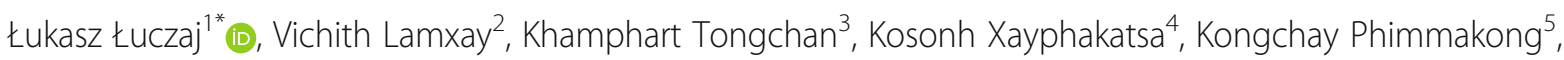 \\ Somphavanh Radavanh ${ }^{4}$, Villapone Kanyasone ${ }^{6}$, Marcin Pietras ${ }^{7}$ and Małgorzata Karbarz ${ }^{1}$
}

\begin{abstract}
Background: Open air markets hold an important position for ethnobiologists. In Southeast Asia, they are seriously understudied, in spite of their incredible biocultural diversity. In order to fill this gap we recorded plants and fungi sold in the open air markets of Luang Prabang, Lao PDR.

Methods: The markets were visited 38 times in four seasons: the dry season, early monsoon, mid-monsoon, and end-of-monsoon, at least 8 times per season. All items were photographed and voucher specimens were collected. Fungi were identified using DNA barcoding techniques.

Results: We recorded 110 species of wild edible plants and 54 species of fungi, including 49 wild-collected species. The sold plants included 86 species of green vegetables, 18 species of fruits and 3 species of flowers. Products from woody species constitute around half of all taxa sold. These include the young shoots of tree leaves, which are used for salads - an interesting feature of Lao cuisine. A large number of extremely rare Russula, with no reference sequences represented in databases or even species unknown to science is present on sale in the markets.

Conclusions: Luang Prabang markets are some of the richest in species of wild edible plants and fungi in Asia, and indeed in the whole world. It is worth pointing out the exceptionally long list of wild edible mushrooms which are sold in Luang Prabang (and probably elsewhere in Laos). We view the Morning Market of Luang Prabang as a cultural treasure that unites the traditions of eating a large number of living species with very diverse flora and fauna. Measures should be taken to strike a balance between local foraging traditions and nature conservation priorities.
\end{abstract}

Keywords: Wild edible plants, Wild vegetables, Edible mushrooms, Mekong region, Ethnobotany, Ethnomycology

\section{Background}

Open air markets hold an important position for ethnobiologists [1-3]. They are places where one can usually find the plants, animals, and fungi which are most important to a given culture, e.g., commonly eaten fruits, vegetables, or medicinal plants. Of course, some highly valued goods-plants with a sacred status (like entheogens) or illegal items, such as protected bush meat-may

\footnotetext{
*Correspondence: lukasz.luczaj@interia.pl

'Institute of Biology and Biotechnology, ul. Pigonia 1, 35-310 Rzeszów, Poland

Full list of author information is available at the end of the article
}

not be present in open air markets, but the bulk of most commonly consumed organisms usually is. Ethnobotanical studies of open air markets are a frequent topic of ethnobotanical enquiry and they have been performed in most geographical regions, including several countries of Eurasia (e.g., [4-37]). The oldest known ethnobiological market surveys were carried out by Hungarian and Polish researchers in the early twentieth century, in Budapest [38, 39], Wilno (now Vilnius in Lithuania) [40] and Poznań $[41,42]$. Recently, return studies in the markets of Budapest and Poznań showed large changes in the list of sold plants and fungi compared to what was 
sold in the beginning of the twentieth century [4, 43]. Bye's study from Mexico [1]was another important early work based on market surveys.

Ethnobiological studies of markets are an ethnobiologist's entry point to local food systems. This research situation allows for establishing quick contact with plant sellers (who are often responsible for their collection, or whose families collect the plants for them). The meeting in a public space enables a quick exchange of information of an ethnobiological character, concerning names of the sold organisms, their occurrence and properties. One of the disadvantages of market surveys is sometimes the difficulty of collecting classic voucher specimens, as usually only organs or parts of plants are on sale [2]. Fortunately, the difficulties in proper biological identification of these fragmentary items can be overcome by DNA barcoding [28, 31, 37].

Bearing in mind how easy it is to perform a market study, it is surprising that there are many parts of the world in which such studies have been made rarely or not at all. Open air markets are an important part of the eastern and south Asian rural economy, and even though Asia is the largest, most populous, and perhaps the most diverse of all continents, such studies are quite few and far between ([4-33];). Although surveys of wild edible plants and fungi sold in Southeast Asia are rare, some research effort has been put into studying the socioeconomic aspects of "green" open markets in general [44-47] as well as the contamination of plants with heavy metals [48] or parasites and pathogens [49-51]. Some studies from Southeast Asia performed in open air markets concern plant genetic resources from a single species, genus or family; the identification of the main cultivated plants (e.g., [52-56]); or medicinal plants $[24,57]$.

Lao PDR is a diverse country with over 40 ethnic minorities and 11 thousand vascular plants species. Due to the very turbulent political and economic situation in Southeast Asia in the twentieth century, the biological diversity of Laos is still poorly described, in spite of increasing efforts to document its Traditional Knowledge and identify its non-timber forest products [58-69].

No lists of plants or fungi sold in particular markets have ever been published in Laos apart from a list of wild vegetables collected in rice fields and sold locally in Houaphan Province [23]. More surveys concerning animals, both vertebrates [70-73] and insects [74], have been performed. Some new species have been found in Lao markets, e.g., a new species of Impatiens (a dicot plant) [75] and a new species of rodent belonging to a new family, which was found being sold for meat in a local market [76]. Wildlife-both flora and fauna-is present in most Lao markets. Wild plants and animals are an important part of national cuisine, both because of the country's low economic status, but also because of low human density, easy access to nature and widespread beliefs about the health benefits of eating wild foods. In a recent quick survey of 7 Lao markets, mammals from as many as 12 families were recorded for sale as bush meat [72].

All the towns in Laos have one or a few markets where both cultivated and wild products are sold. Luang Prabang is one of the largest towns in Laos, with a population of 90,000 people. It is the biggest tourist hotspot of the country. Luang Prabang used to be the capital of Laos until 1975 and hosts many monuments important to the history of the country. As it is located in the center of the city, the Morning Market in the center of the historical part of Luang Prabang is probably the market most visited by foreigners. In spite of this, although some products are tourist-oriented, it mainly serves the local community. Thus, numerous vegetables, fruits, and wild and domesticated animals are sold there each day. A few other open air markets are located in the city and its peripheries.

Lao markets are worth investigating not only in search of endangered and rare organisms. Lao cuisine is very rich in ingredients [77] and many wild vegetables and fungi are gathered. Lao PDR is undergoing deep cultural changes as it is becomes increasingly involved in the global market economy, and traditional subsistence economy is gradually being replaced by commercial agriculture and the tourist industry, especially in towns. The richness of Lao NTFP products and local traditions of plant use have attracted a lot of research attention in the last three decades, but what is sold in the local markets was never a subject of study. The traditional foods of the Luang Prabang royal court in the mid-twentieth century were documented in a unique cook book written by the king's cook, Phia Sing [77]. A provisional list of edible plants used in Laos was reported by Jaques Vidal in the mid-twentieth century, with one of the main sites of observation being Luang Prabang [78-80].

Mushrooms are an important part of Lao cuisine and a commonly exploited NTFP. That is why they are featured in many local rural development studies and some attempts have been made to list the fungi species most commonly sold in Laos [62-65, 81, 82].

Overall, the aim of our study was to make an inventory of wild edible plants and fungi sold in the markets of Luang Prabang, with special reference to the following issues:

- Documenting traditional foods.

- Monitoring the presence of any endangered species.

- The possibility of discovering taxa new to science. 


\section{Methods}

\section{Fieldwork}

The most species-rich Morning Market was surveyed regularly in four different seasons (dry season 10th to 19th of February 2018, end of monsoon/beginning of dry season 10th to 18th of November 2019, early monsoon 31st of May to 10th of June 2019 and midmonsoon 31st of July to 7th of August 2019), each time for 8 to 11 consecutive days - 38 days altogether. All the stalls were visited and most of them were photographed. Voucher specimens of wild vegetables and fungi were taken. Unstructured interviews about the uses and origins of each species were carried out with the market's sellers, with the help of other co-authors or translators. However, they were not recorded. Apart from the Morning Market, four other markets in Luang Prabang (Phousi, Phanluang, Navieng Kham, Sayxoumxon) and two markets $20 \mathrm{~km}$ south of Luang Prabang (north of Xiang Ngeun) were also occasionally monitored and visited at least three times during our research. However, the market with the greatest diversity-the Morning Market-was the main focus. A list of sold taxa was compiled for each season. If possible, plants and fungi were preserved as herbarium specimens and deposited in duplicates: in the herbarium of Warsaw University (WA) and the National Herbarium of Laos (NHL).

\section{Plant and fungi identification}

Plants were identified using local field guides and literature available in our institutions and internet resources, taking into consideration recent Lao plant checklists [83, 84].

Altogether, 109 specimen vouchers of fungi were analyzed. They were first identified morphologically using the only available guide to the mycota of Laos [82]. The collected voucher specimens were identified with DNA barcoding $[85,86]$ following the guidelines of accepted methods for DNA barcoding of fungi [87]. Fungal DNA was extracted from a small part of the sporocarp (ca. 1 $\mathrm{mm}^{3}$ of dry mycelium taken from the cap) using a Plant and Fungi DNA Purification Kit (Eurx), following standard protocol. The PCR cocktail consisted of a $4 \mu \mathrm{l}$ DNA extract, $0.5 \mu \mathrm{l}$ of each of the primers (ITS5/ITS1f and ITS4 in $10 \mathrm{nmol}$ concentration) and a 5- $\mu \mathrm{l}$ Type-it Microsatellite PCR Kit (Qiagen). PCR was carried out using the following thermocycling conditions: an initial 15 min at $95{ }^{\circ} \mathrm{C}$, followed by 35 cycles at $95^{\circ} \mathrm{C}$ for $30 \mathrm{~s}$, $55{ }^{\circ} \mathrm{C}$ for $30 \mathrm{~s}, 72{ }^{\circ} \mathrm{C}$ for $1 \mathrm{~min}$, and a final cycle of 10 min at $72{ }^{\circ} \mathrm{C}$. The PCR products were estimated by running a 5-ml DNA amplicon on $1.5 \%$ agarose gel for 30 min. The PCR products were sequenced using ITS4 or ITS5 primers at the Laboratory of Molecular Biology of Adam Mickiewicz University (Poznań) and at the Institute of Biology and Biotechnology of the University of
Rzeszów. Obtained sequences were compared with published sequences in UNITE databases using the BLAST tool. A positive identification of a specimen was confirmed if they shared > 97\% ITS region sequence identity with the reference sequence. Nuclear ITS sequences obtained in this study have been deposited in GenBank [88] (with the accession numbers listed in Table 3). Nomenclature has been accepted according to the species hypothesis described in UNITE [89].

Plant nomenclature follows the Plant List [90] and fungi names follow Index Fungorum [91].

\section{Wild versus cultivated}

It is important to bear in mind that the studied area is a complex agroforestry ecosystem-the gardens have many trees and the numerous species that surround villages often come from spontaneous regeneration; thus, it is very difficult to establish if certain products come from planted or wild specimens. This concerns for example trees growing within villages as well as plants that are both cultivated and collected from the wild or merely tolerated within the agroecosystem, being a part of incipient cultivation (see e.g., [92]). We assume that wild and cultivated plants constitute a continuum. In our study, we decided to include all plants which are at least sometimes collected from spontaneously selfseeded specimens or plants and which are considered wild by the local population even if they are also cultivated. In this, we follow the emic approach to classifying whether a wild plant is wild (for a discussion of this approach, see paper by Sõukand and Kalle [93]). A very similar problem in identifying what is wild in a Southeast Asian market was encountered by the researchers in the markets of Khon Kaen in the Isaan Province of Thailand [15]. They wrote: "Given the extent to which rural ecosystems in Northeast Thailand have been subject to continuing human interference for hundreds of years, it is often difficult to determine if a species is truly wild or not. Wild species are defined as species that normally grow under natural conditions without deliberate human management" [15]. Further they give examples of star fruit (Averrhoa carambola L.) and tamarind (Tamarindus indica L.) often selfpropagating and considered wild or numerous species transplanted to gardens from wild locations to enhance market yields.

\section{Results}

We recorded the sales of 110 species of wild plants for food purposes (Table 1; Figs. 1, 2, and 3). They belong to 49 plant families. The taxa included 86 species of green wild vegetables, 19 species of fruits, and 3 species of flowers. Among plants, the most represented plant families were Fabaceae, Poaceae, Solanaceae, and 


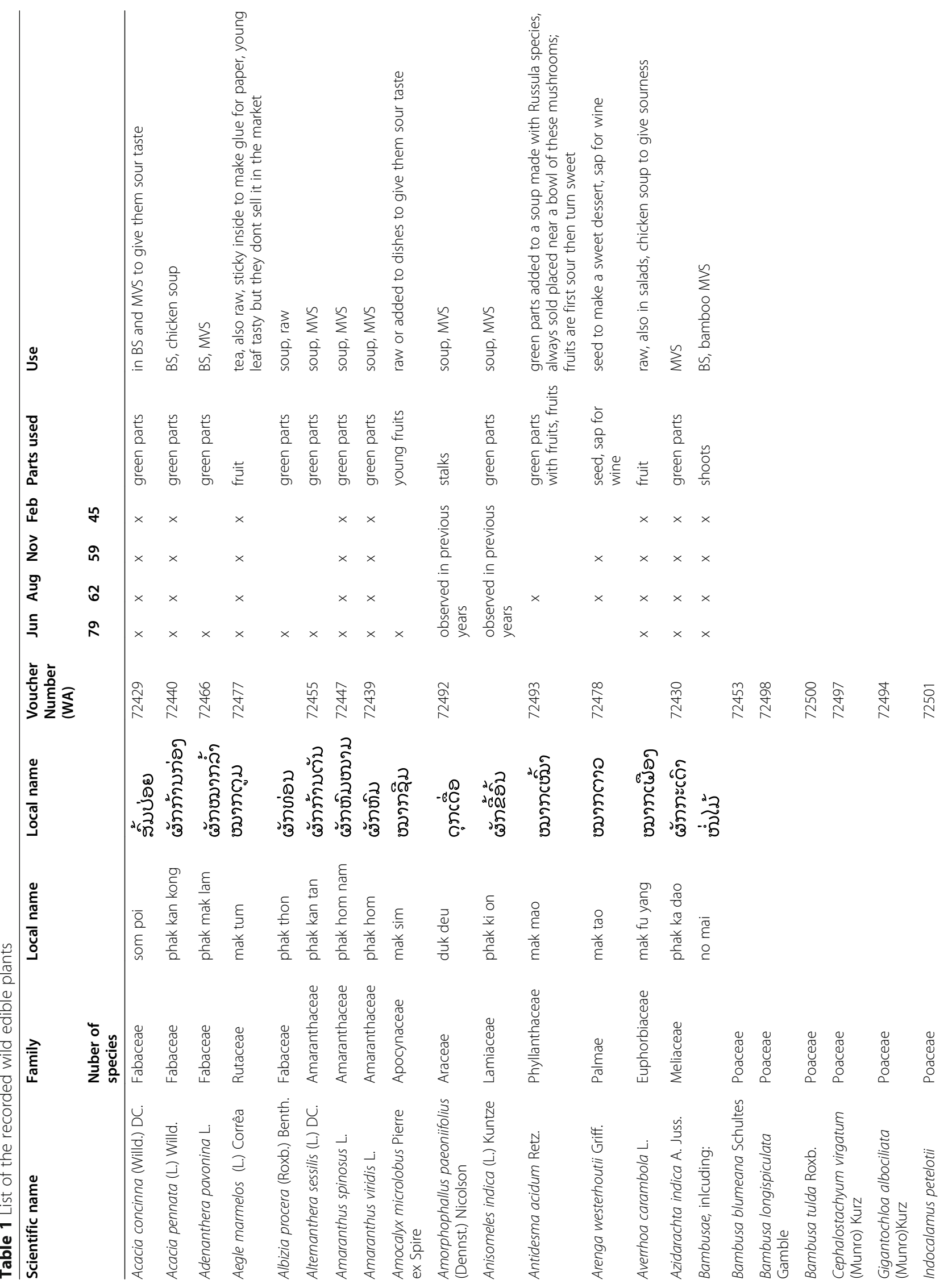




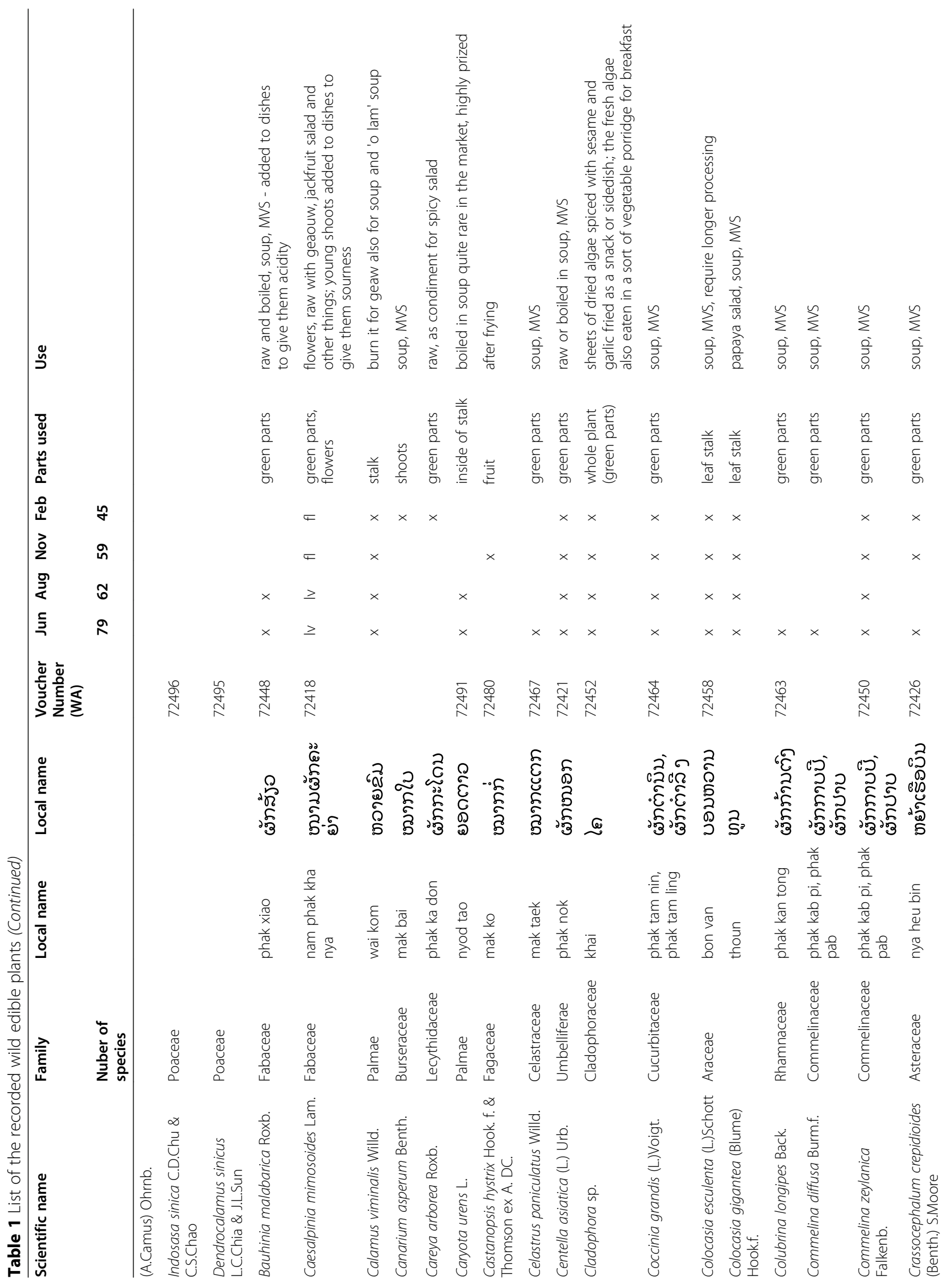




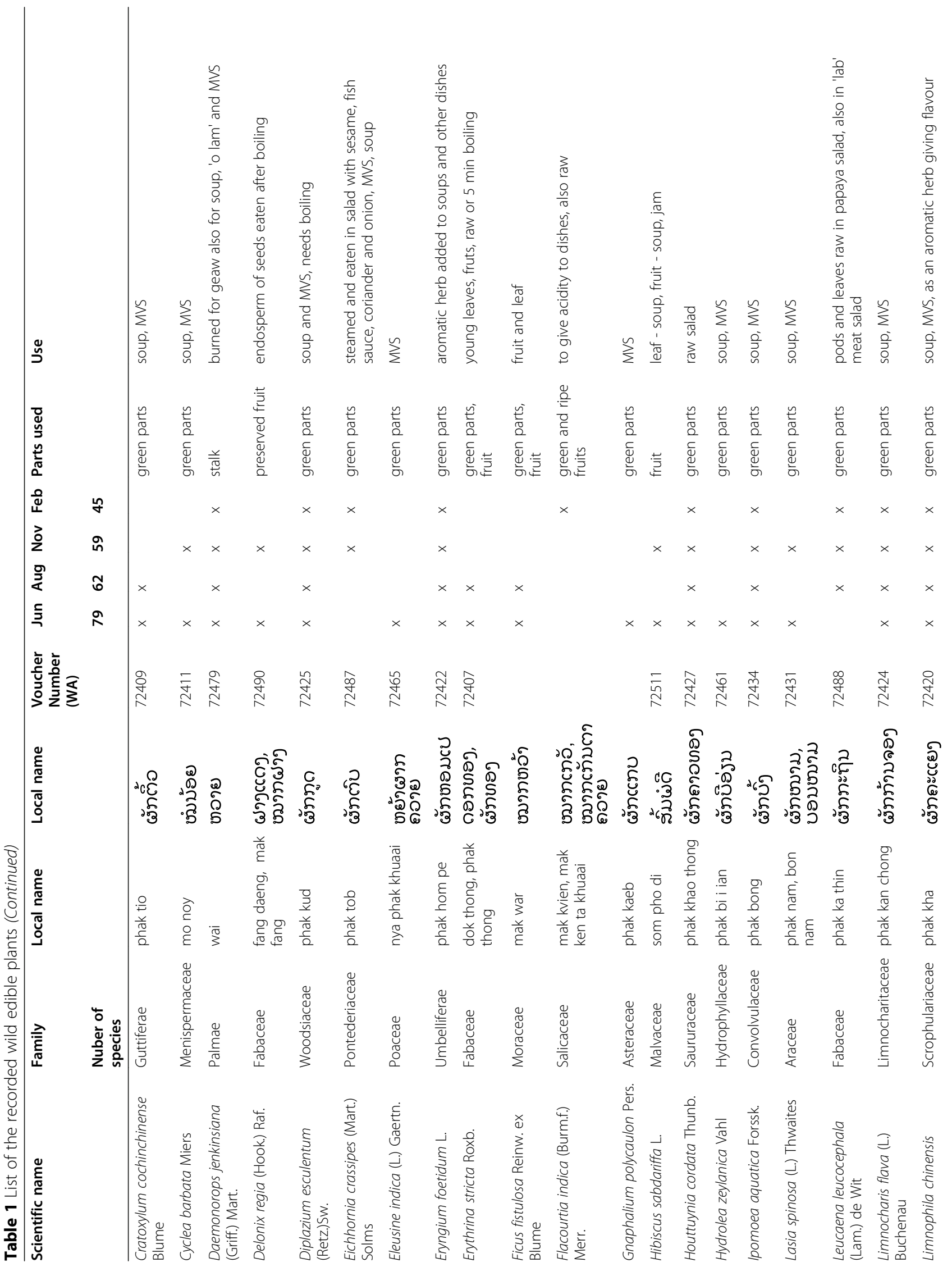




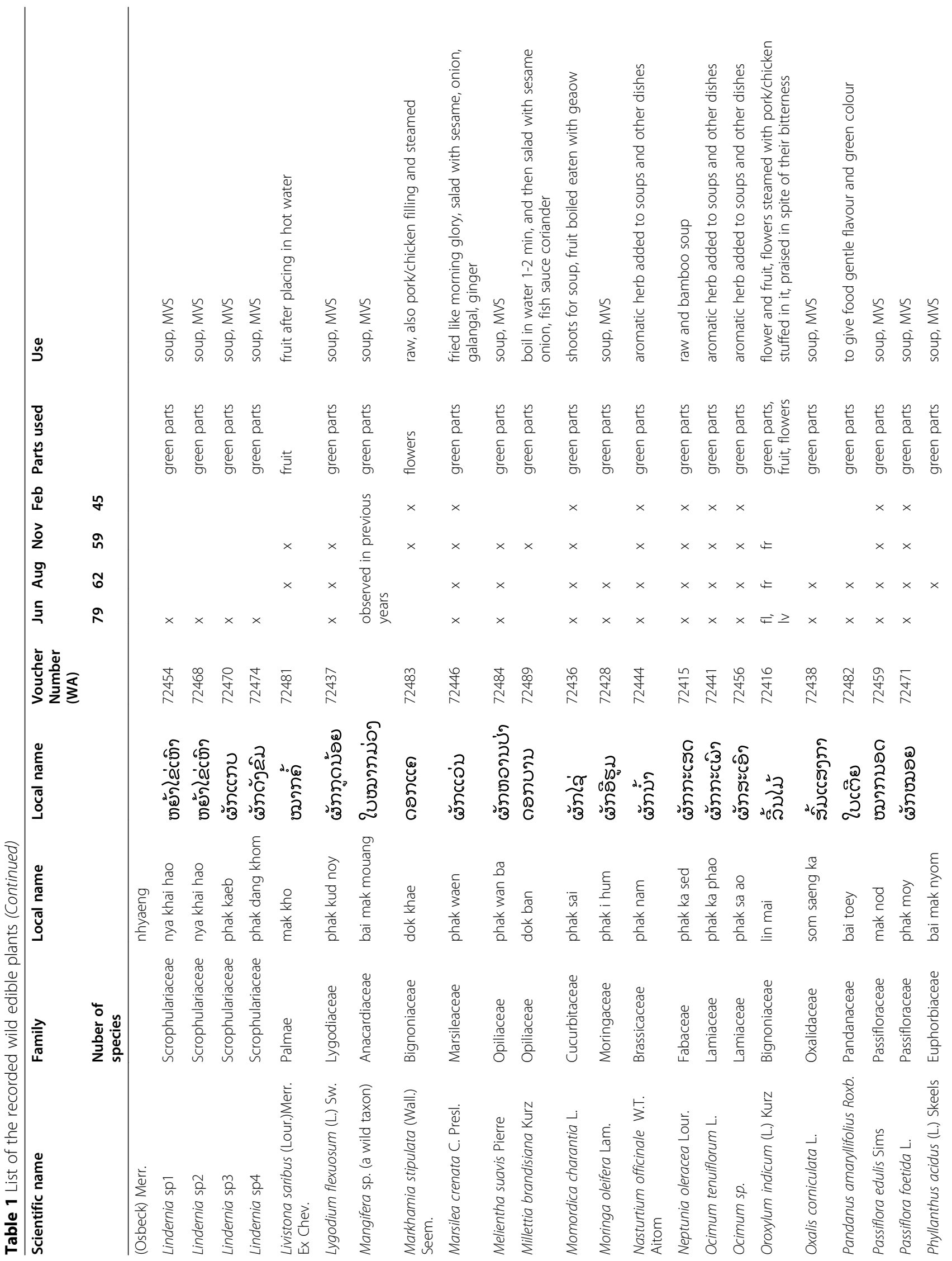




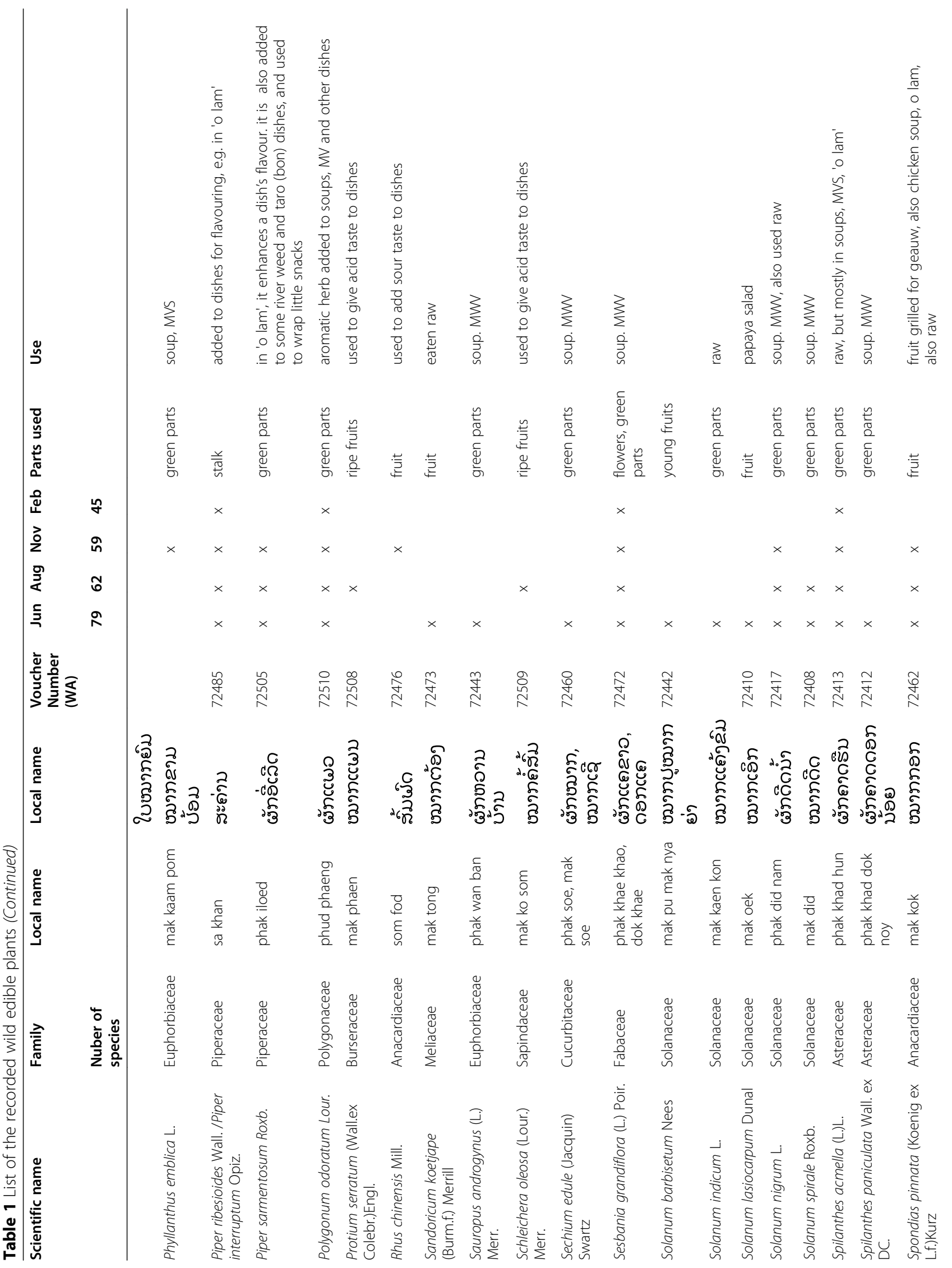




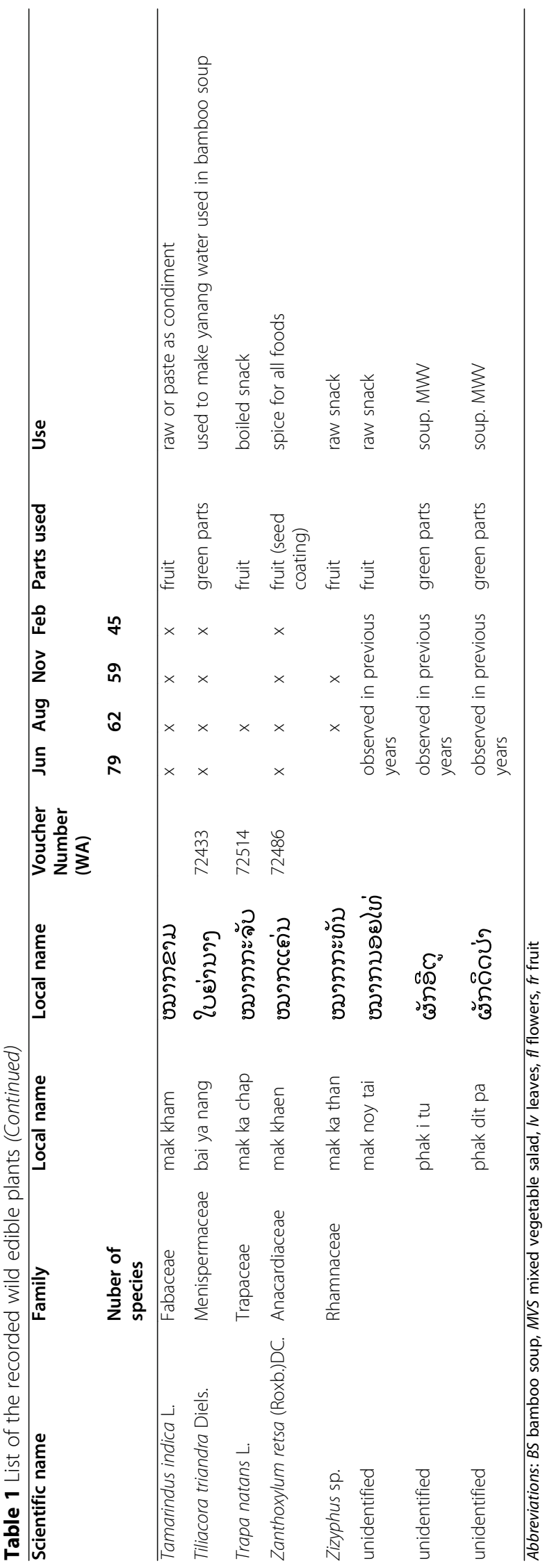



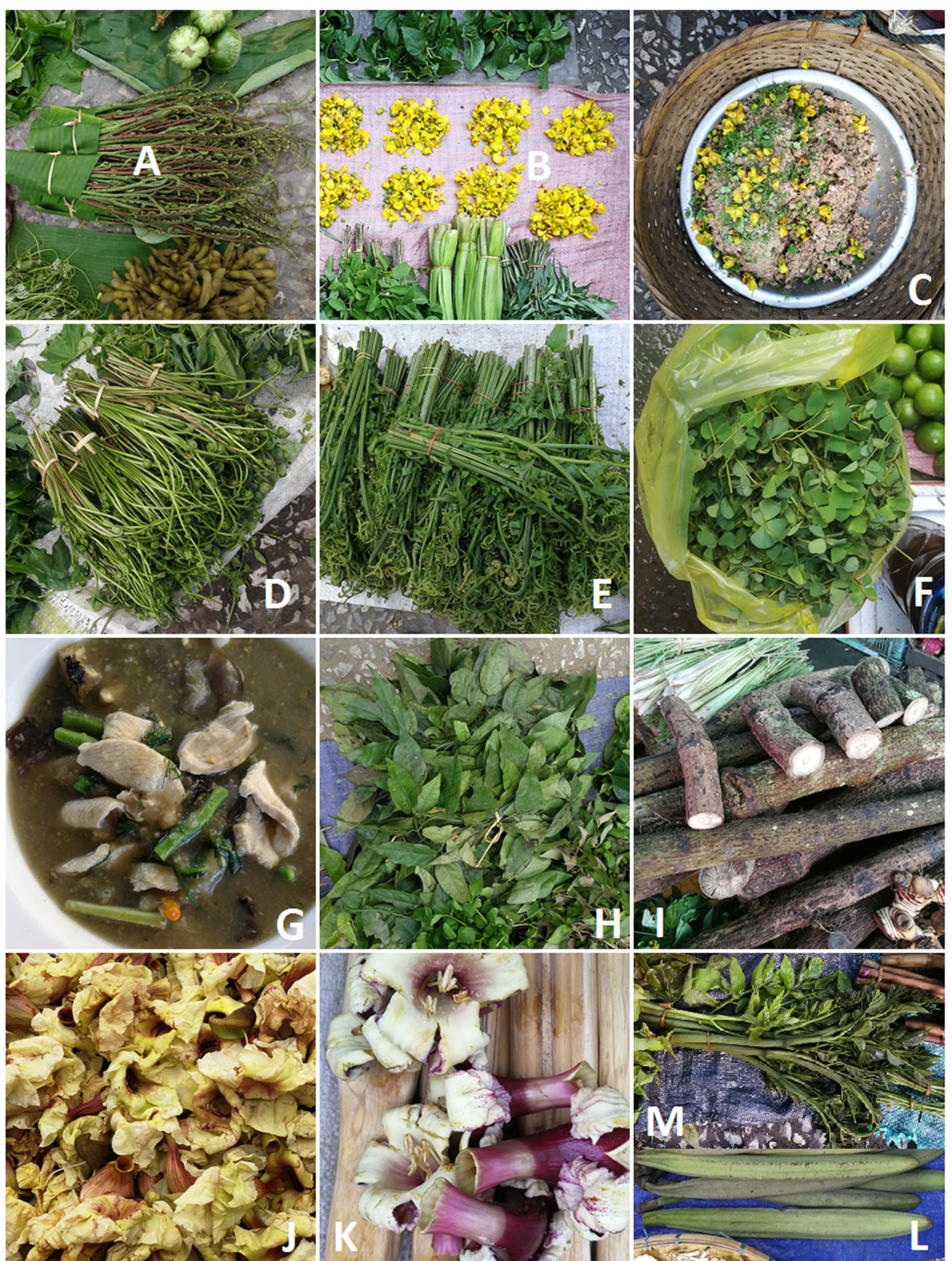

Fig. 1 (See legend on next page.) 
(See figure on previous page.)

Fig. 1 Selected edible plants sold in the markets. a-c Caesalpinia mimosoides: shoots (a), flowers (b), and flowers in traditional unripe jackfruit salad sold in the morning market; ferns: $\mathbf{d}$ Lygodium flexuosum. e Diplazium esculentum. f Marsilea crenata. $\mathbf{g}$ o lam, a traditional Luang Prabang stewed dish containing numerous wild ingredients served in restaurants in the city; some of its ingredients include wood of sakhan pepper (Piper ribesioides) (h) and juice from bai yanang (Tiliacora triandra) leaves (i). j Flowers of Markhamia stipulata. $\mathbf{k}-\mathbf{m}$ Orophyllum indicum: flowers (k), unripe fruits (I), young leafy shoots $(\mathbf{m})$

Scrophulariaceae. Woody plants (trees, shrubs, and woody vines) constitute exactly half (50\%) of the plants sold, and among them $36 \%$ are trees (bamboos were not included in this calculation).

The largest number of taxa was available in the early monsoon season (June), with a slightly lower number in the mid-monsoon and on the turn of the monsoon and dry season. A much lower choice of plants was available in the dry season (Table 1). However, in each season (observation period), some plants were observed which were not present in other periods.

Molecular investigation and morphological observation revealed a total of 54 fungal taxa from 17 fungi families (Tables 2 and 3; Figs. 3, 4, 5, and 6). Of these, 37 taxa were assigned down to species level and the rest to genus level. Russulaceae was best represented among fungi. The extraction of genetic material failed for some specimens; therefore, they could only be identified morphologically. The most common fungi sold in open air market were russuloid fungi, representing 16 taxa. Within this group, seven taxa were identified to species level and nine to genera. Some differences between obtained sequences were recorded in this group. The phylogenetic analysis of ITS sequences placed these taxa in separate clades. Therefore, 9 unique taxa of unidentified Russula species have been distinguished, each with low similarity to the reference sequence (Table 3). Additionally, the differences between obtained Russula' sequences was higher than $3 \%$, which is the expected level of interspecific variation for fungi within ITS. This allows us to assume that a large number of extremely rare Russula, with no reference sequences represented in databases, or even species unknown to science may be present on sale in the markets.

\section{Discussion}

The number of food taxa sold in the studied markets is remarkable on a world scale (see e.g., a list of ethnobotanical market studies in Eurasia in a recent paper about Armenia [94]). We should especially note the long list of 54 fungi species sold, comparable to some of the markets of Mexico (over 90 species sold in 12 local markets [95] and 40 species in another market [96]) and Central Europe, e.g., Poland-32 species in Rzeszów [31], 56 species in Poznań [41] or Hungary, with 38 species in Budapest $[38,39]$. Such a large number of fungi taxa on sale have not yet been recorded anywhere in Asia outside Laos. Only 6 fungi species have been recorded in the Isaan Province of Thailand, which is culturally very close to Laos [15]. Two studies from Yunnan, China, both found 18 species of fungi on sale [14, 32]. In Armenia, 12 species of fungi are sold in the markets of its capital city-Yerevan [94]. Some of the Russula taxa recorded on sale in Luang Prabang may potentially be new species, but, due to the extremely complex taxonomy of the genus, we did not undertake the challenge of describing them. Also, some taxa found in the markets, i.e., Pisolithus orientalis, Polyporus udus, and Calvatia sp. have not been reported as used for consumption in Laos before.

The number of wild food plants-110-is also impressive. For comparison, in Khon Kaen (Bang Lam Phu) located in the Isaan Province, a neighboring region of Thailand, Shirai et al. recorded only half as many species (54) as we found in Luang Prabang [15]. Out of these 54 species 22 were recorded in Luang Prabang as well. In Jinping, Yunnan, China, 35 species of wild food plants were sold in markets [97]; in an area of Assam, India-29 [25]; in the Ukhrul District of Manipur, India [26] - 55; and only 28 species of wild vegetables (out of 132 of all the plant taxa in the market) were found in a study of 10 markets in Myanmar [98].

The diversity of wild food plants sold can only be compared to Xishuangbangna in Yunnan, China, where 146 species were recorded in 10 markets [14]; to Armenia, where in Yerevan, the capital of the country, 148 wild food species were recorded on sale [94]; or to Turkey, where 143 wild edible plants were found in Mugla, Bodrum [9].

A large group of species sold are wild vegetables: leaves, shoots, inner stems, or flowers which are ingredients of traditional dishes. They are mainly used to make a dish called soup phak, a gently boiled salad flavored with spices. Sometimes the species are sold in a mix. A previous paper from another part of Laos (Houphan) reports the use of mainly wild vegetable mixes [23], but here in Luang Prabang, most species are sold in bunches of single species. Only small rice field weeds are sold in a mix.

It is worth emphasizing that a large proportion of wild vegetables in the markets of Luang Prabang come from woody taxa. In most countries, agricultural weeds 

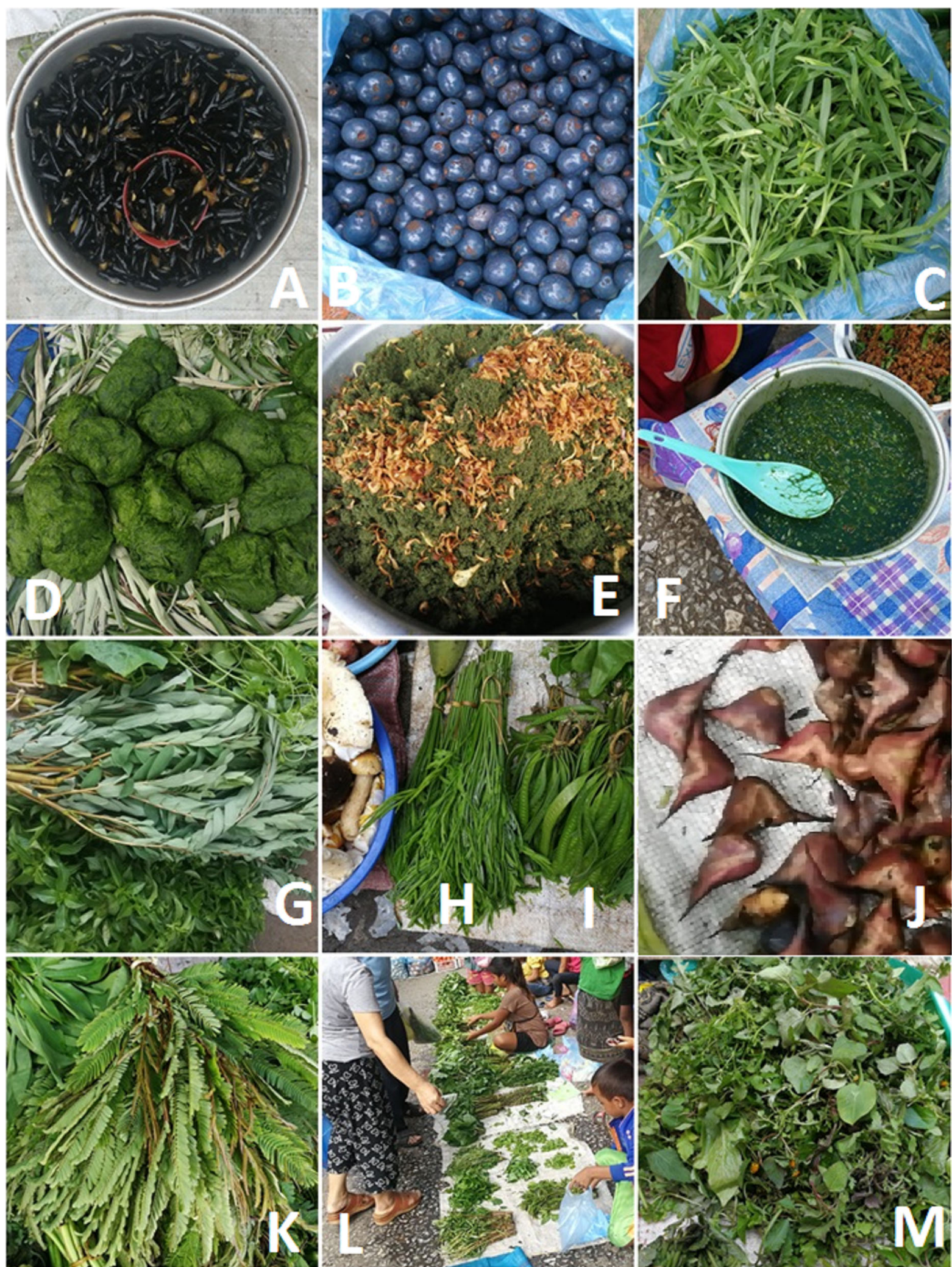

Fig. 2 Selected edible plants sold in the markets. a Processed fruits of Delonix regia. b Fruits of Livistona saribus. c Young shoots of Eleusine indica. $\mathbf{d}-\mathbf{f}$ Cladophora sp., raw plants (d), fried (e), boiled served as breakfast soup in the market (f). $\mathbf{g}$ Moringa oleifera. $\mathbf{h}$ Acacia pennata. i Leucaena leucocephala. $\mathbf{j}$ Trapa natans. $\mathbf{k}$ Acacia concinna. I Sellers of wild vegetables. $\mathbf{m}$ A mix of wild vegetables, mainly weeds of rice fields 

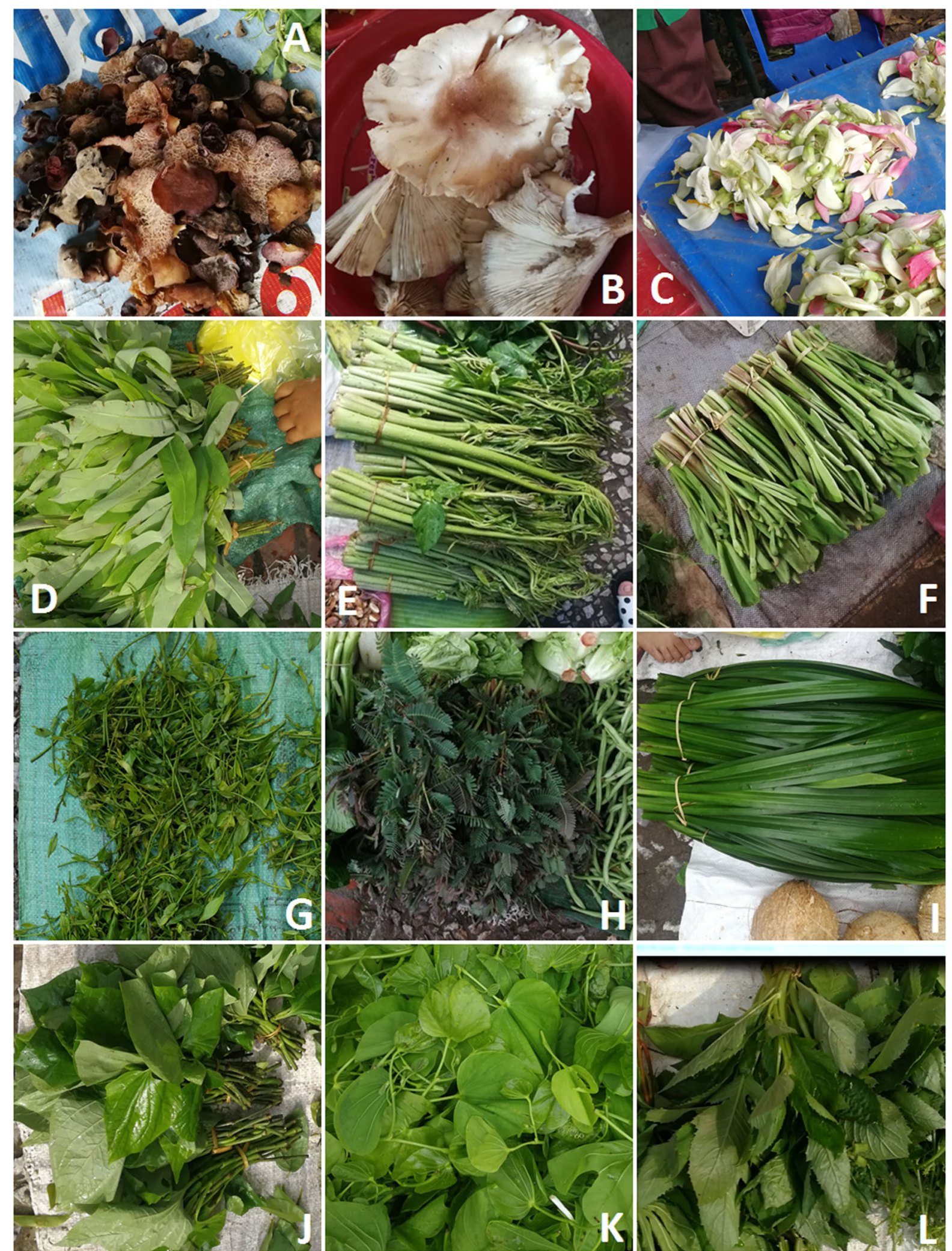

Fig. 3 Selected edible fungi and plants sold in the markets. a Auricularia spp., mainly A. delica. b Pleurotus giganteus. c Flowers of Sesbania grandiflora. d Cratoxylum cochinchinense. e Lasia spinosa. f Limnocharis flava. $\mathbf{g}$ Meliantha suavis. $\mathbf{h}$ Neptunia oleracea. i Pandanus amaryliifolius. j Piper sarmentosum. $\mathbf{k}$ Bauhinia malabarica. I Crassocephalum crepidioides 


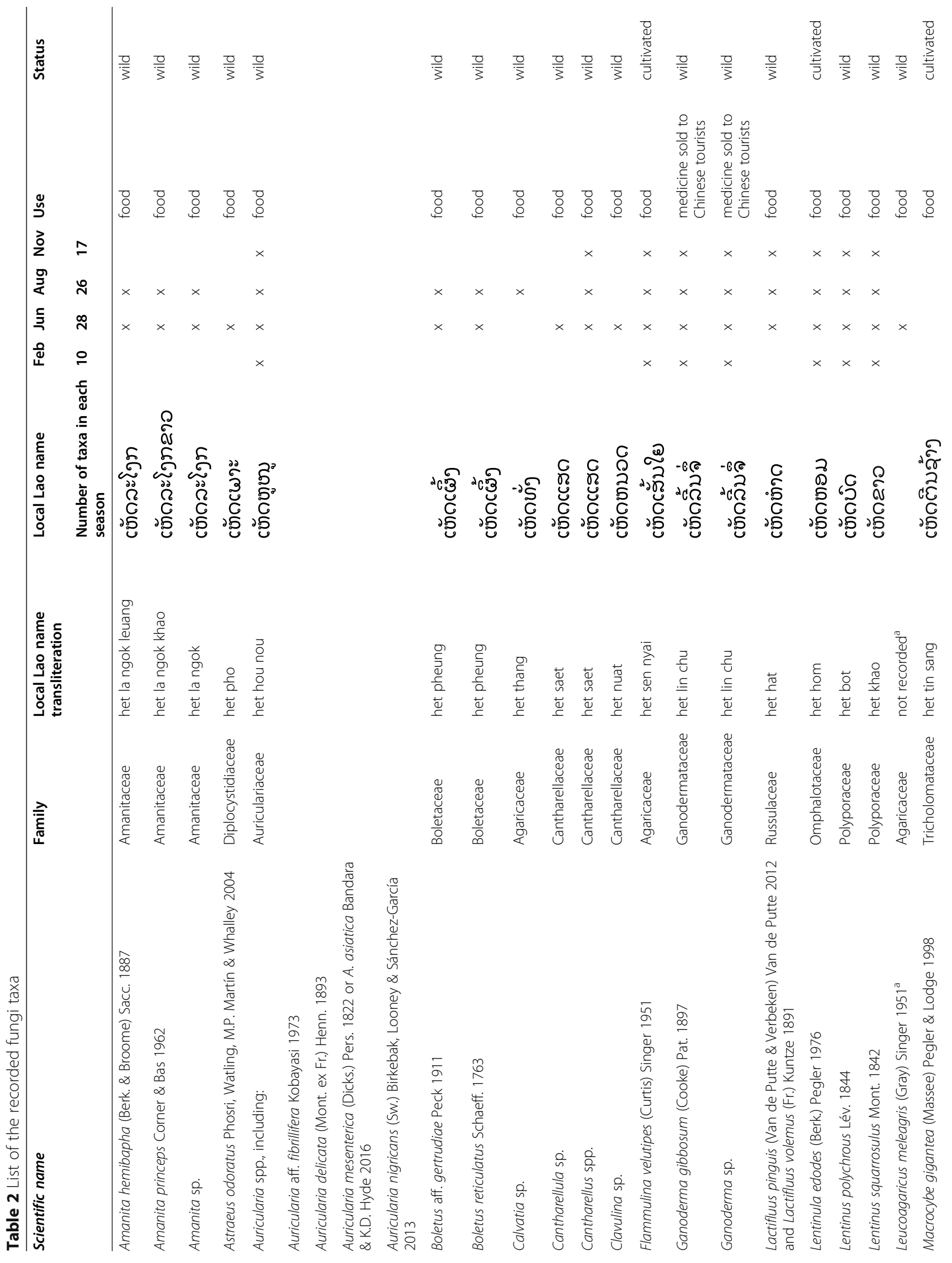




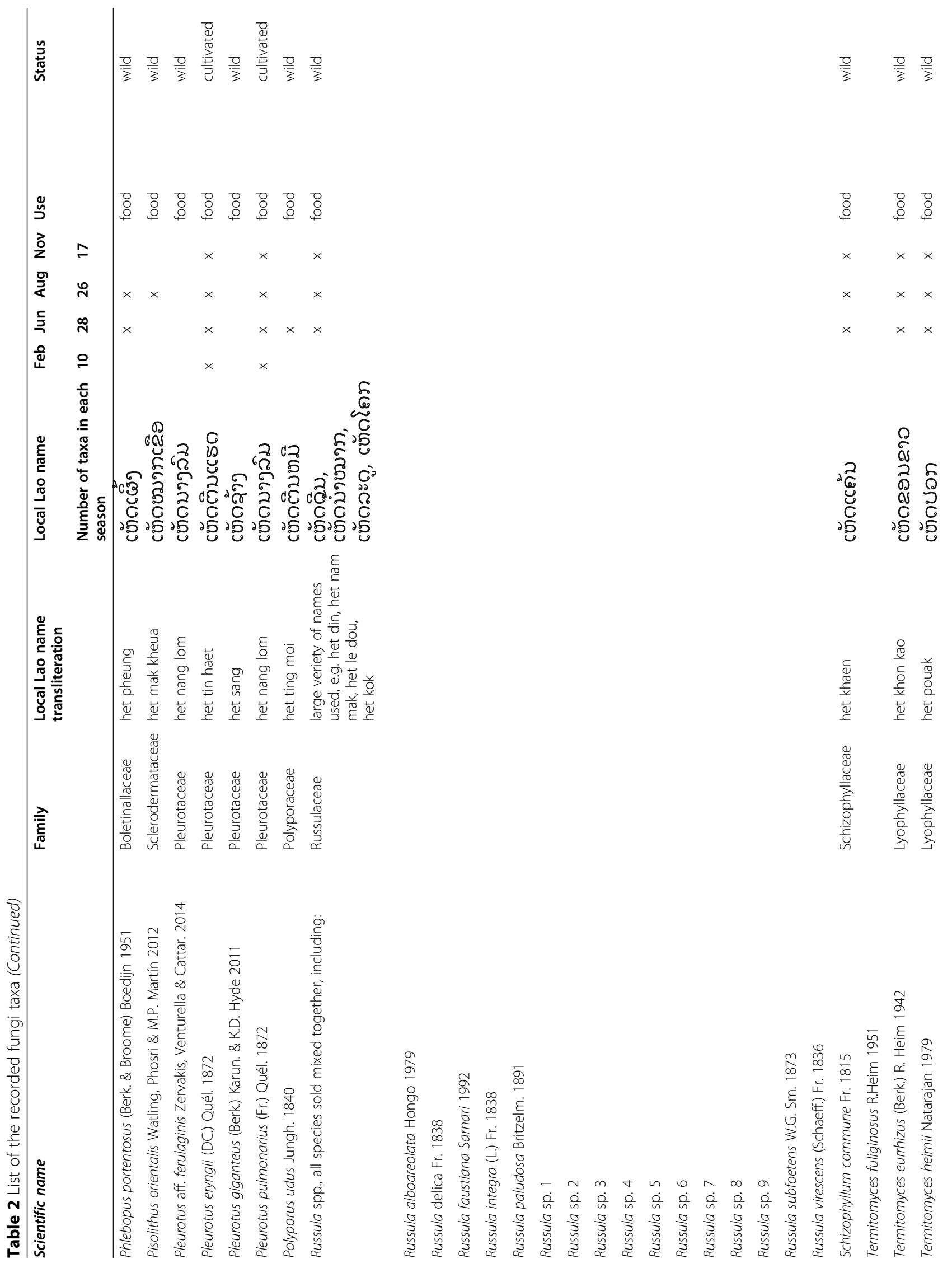




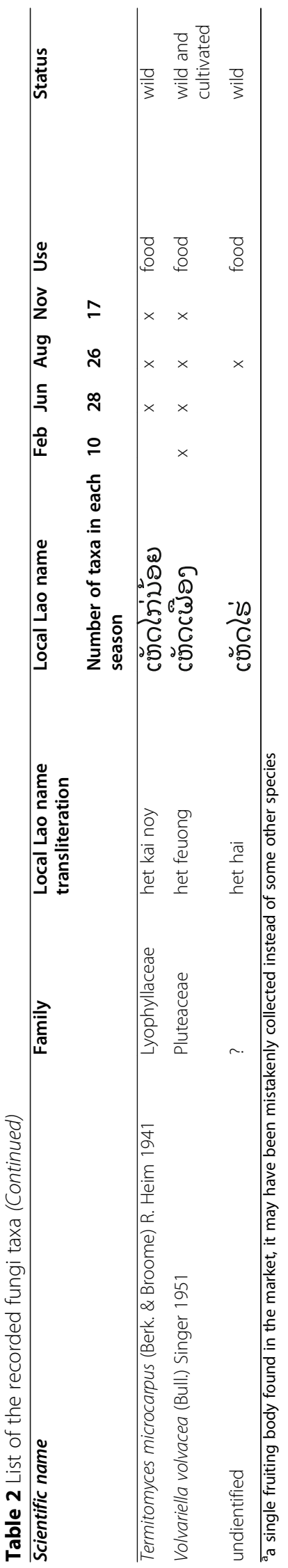




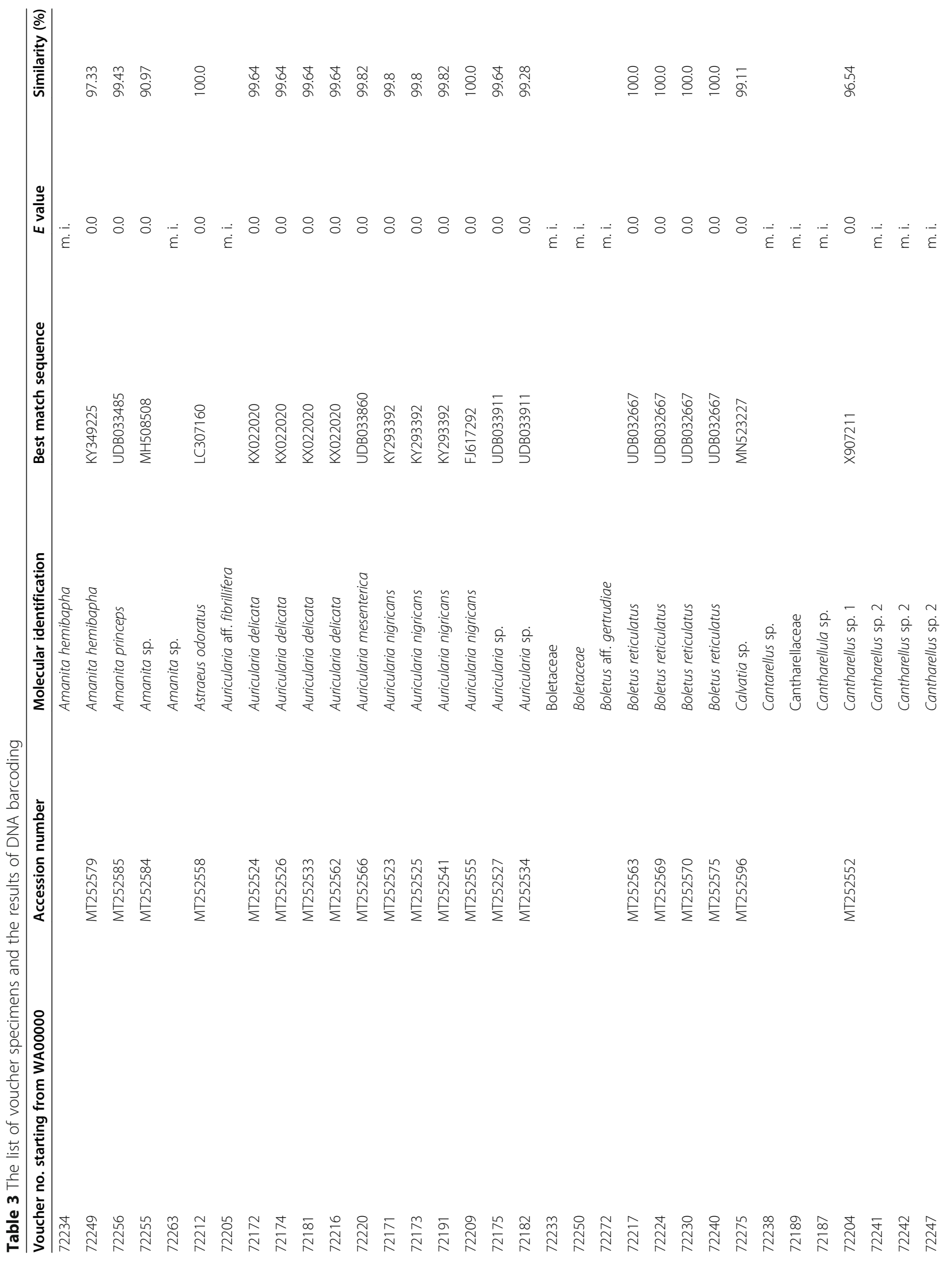




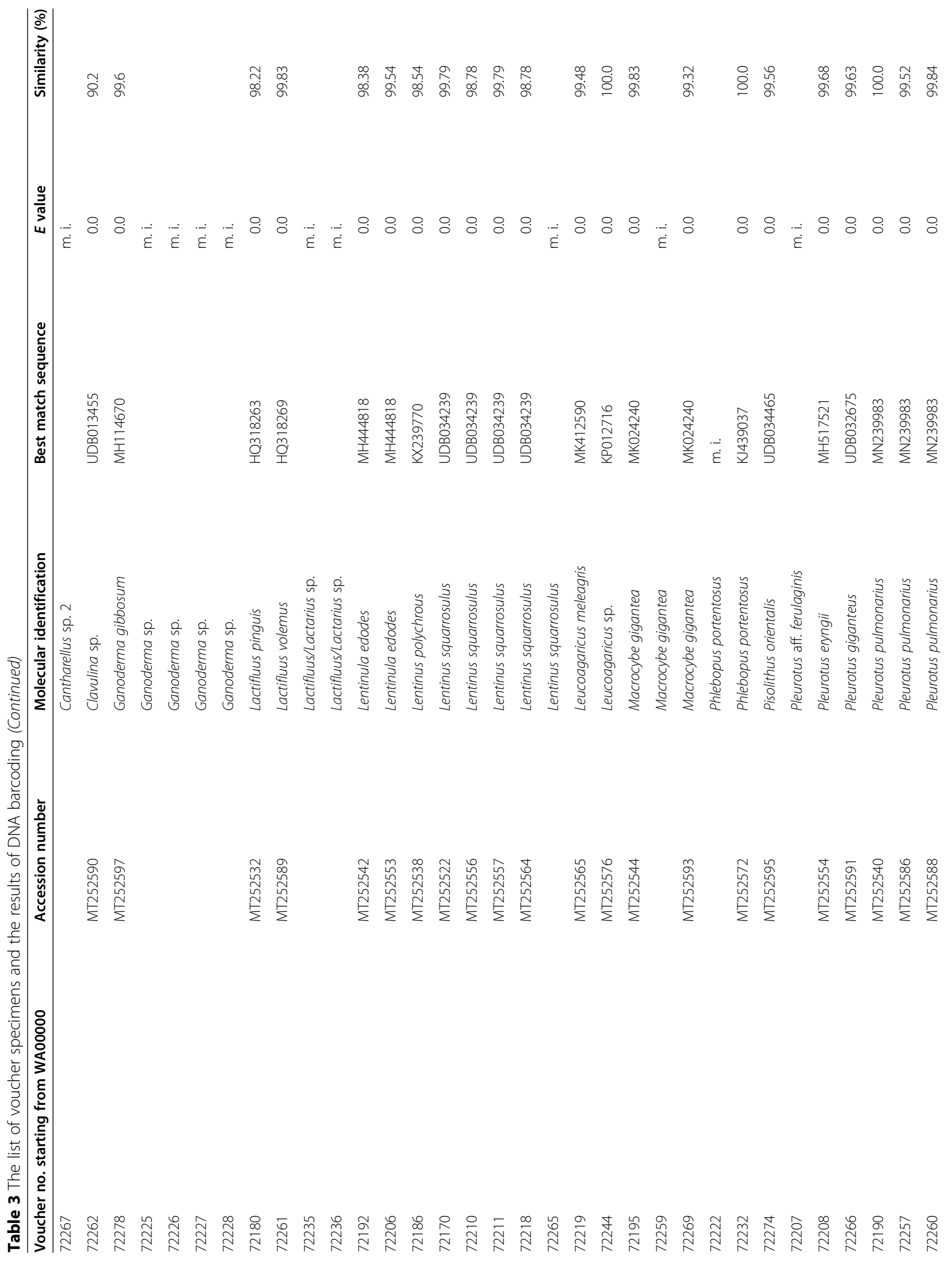




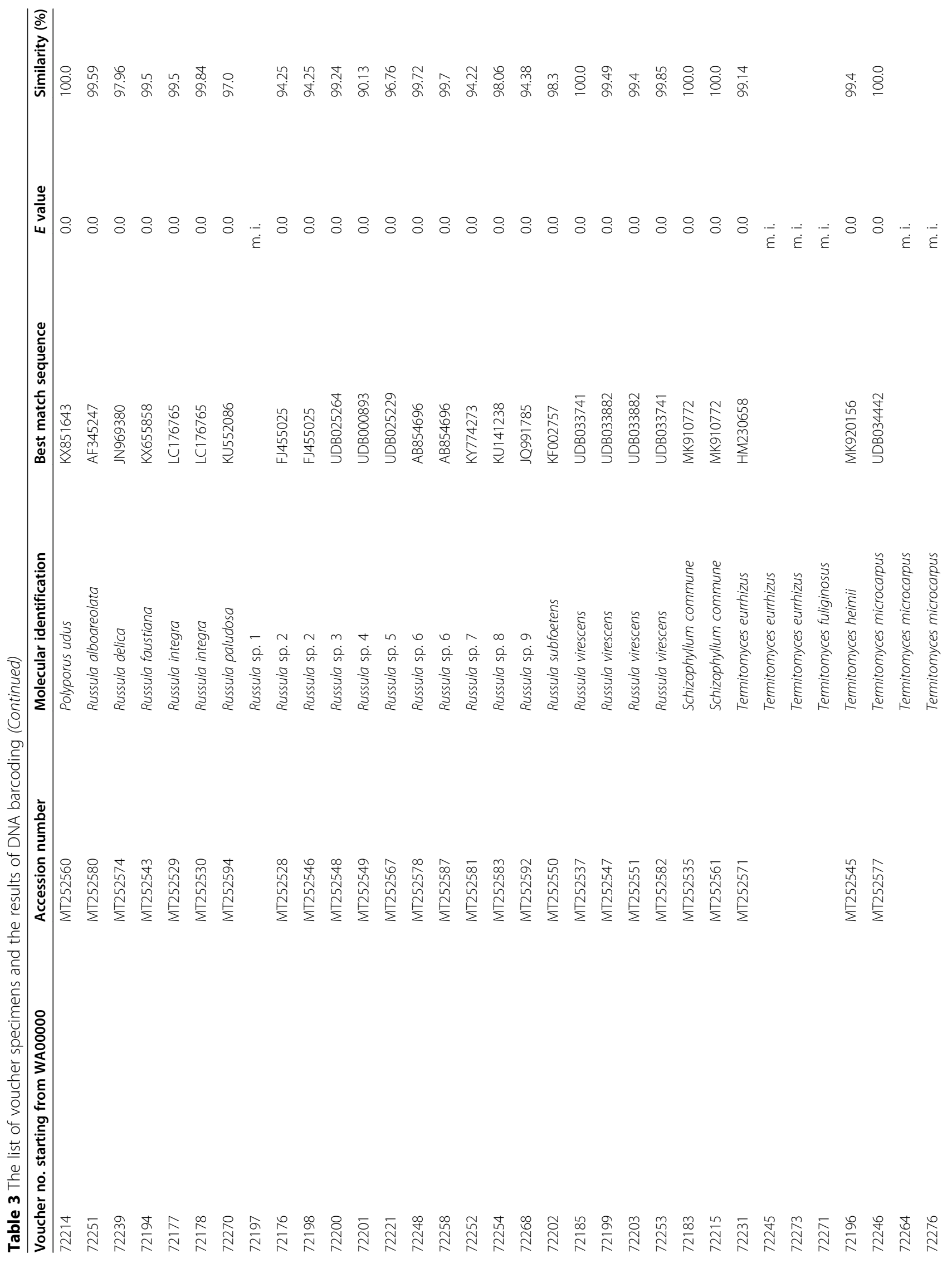




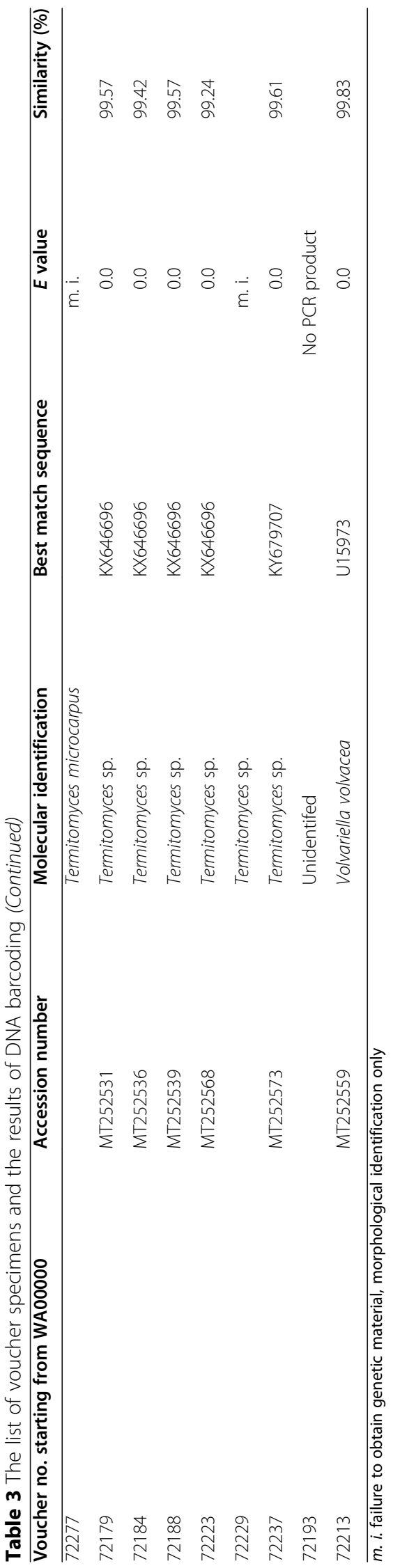




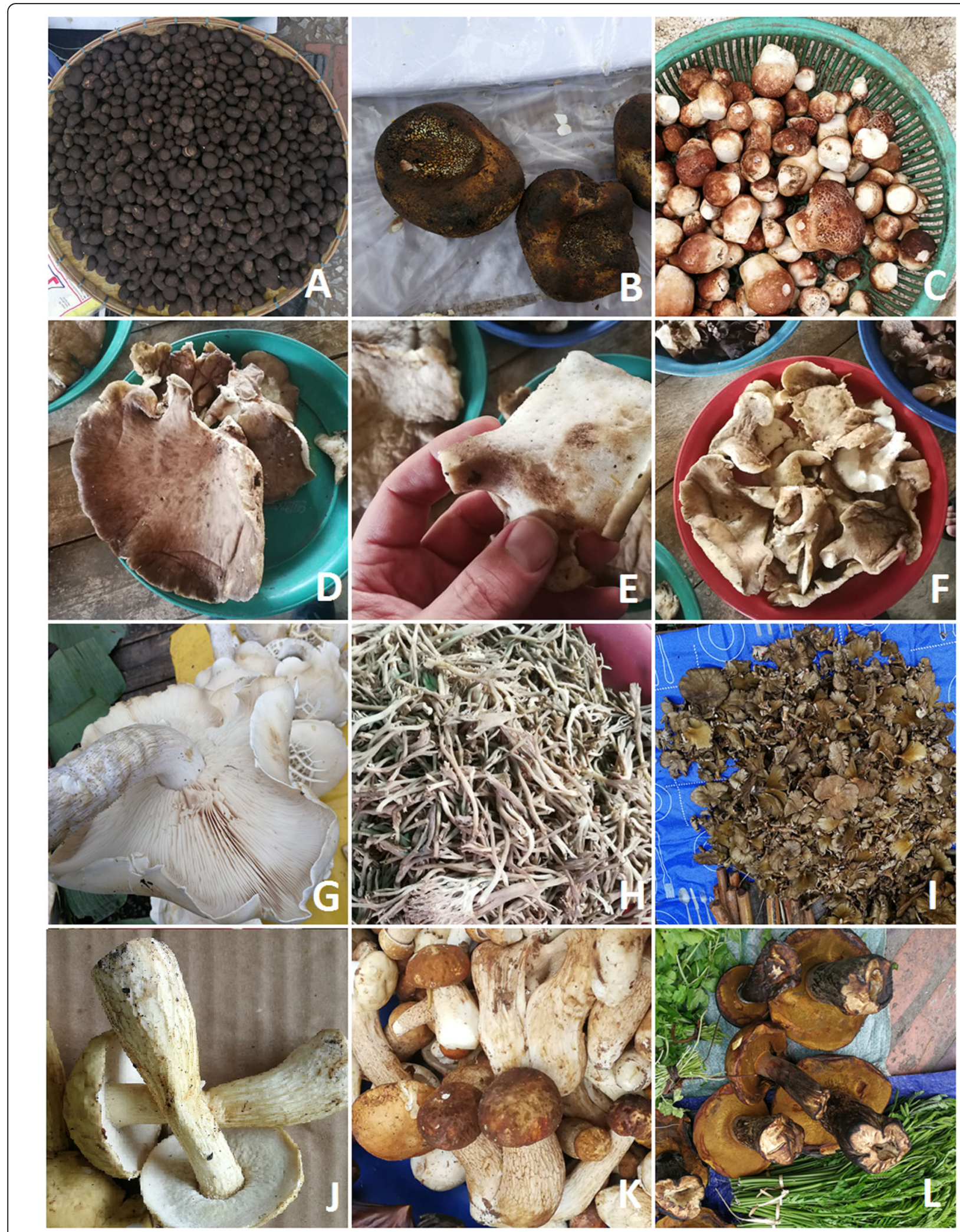

Fig. 4 Selected edible fungi sold in the studied markets. a Astraeus odoratus. b Pisolithus orientalis. c Calvatia sp. d-f Polyporus udus. g Macrocybe gigantea. h Clavulina sp. i Schizophyllum commune. j Boletus of gertrudiae. $\mathbf{k}$ B. reticulatus. I Phlebotus portentosus 

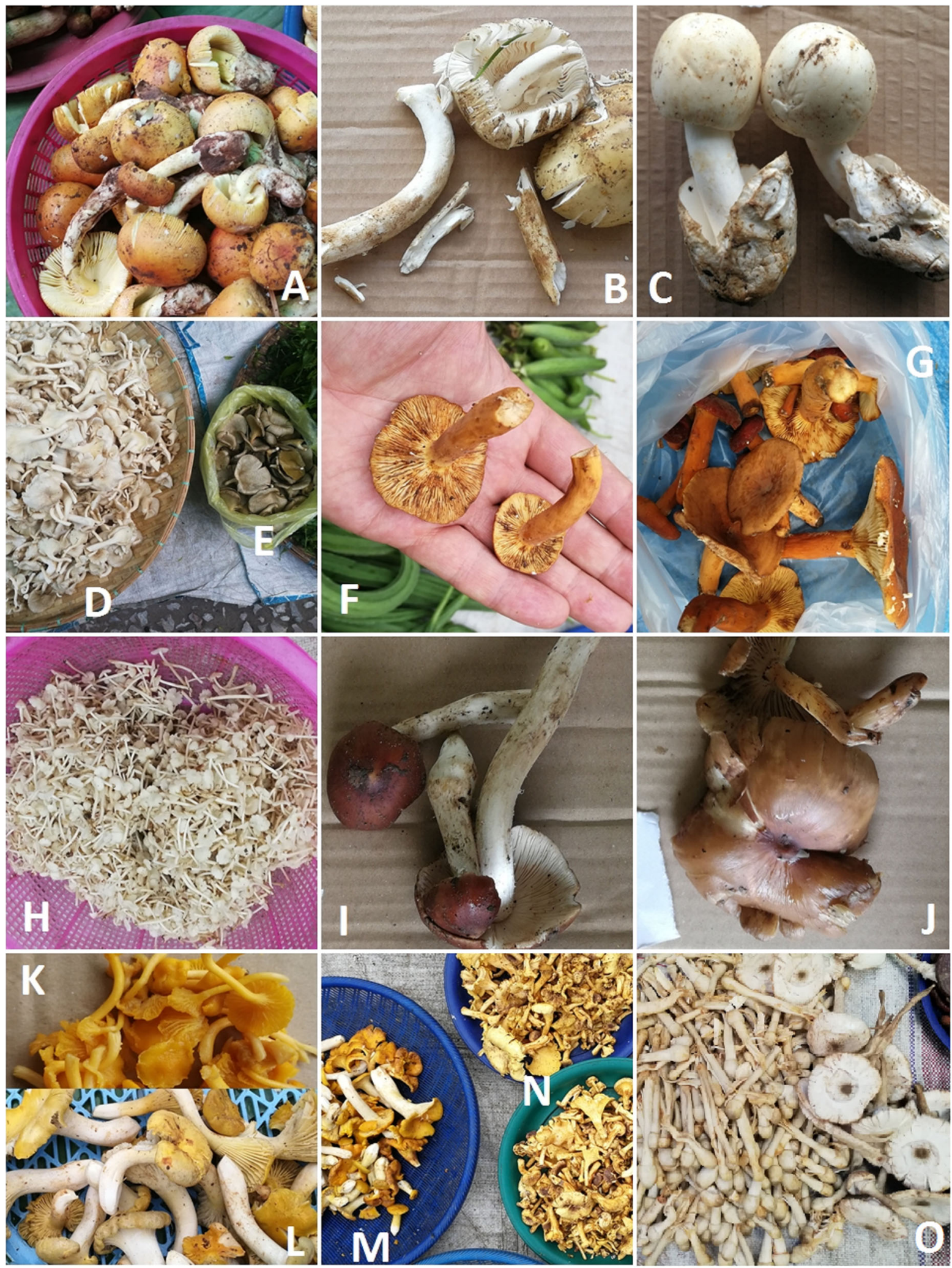

Fig. 5 Selected edible fungi sold in the studied markets. a Amanita hemibapha. b Amanita princeps. c Amanita sp. d Lentinus squarrulosus. e $L$. polychrous. $\mathbf{f}$ Lactarius pinguis. $\mathbf{g}$ L. volemus. $\mathbf{h}$ Termitomyces microcarpus. i T. eurhizus. $\mathbf{j}$ T. fuliginosus. $\mathbf{k}$ The diversity of Cantharellus spp. I Termitomyces heimii 


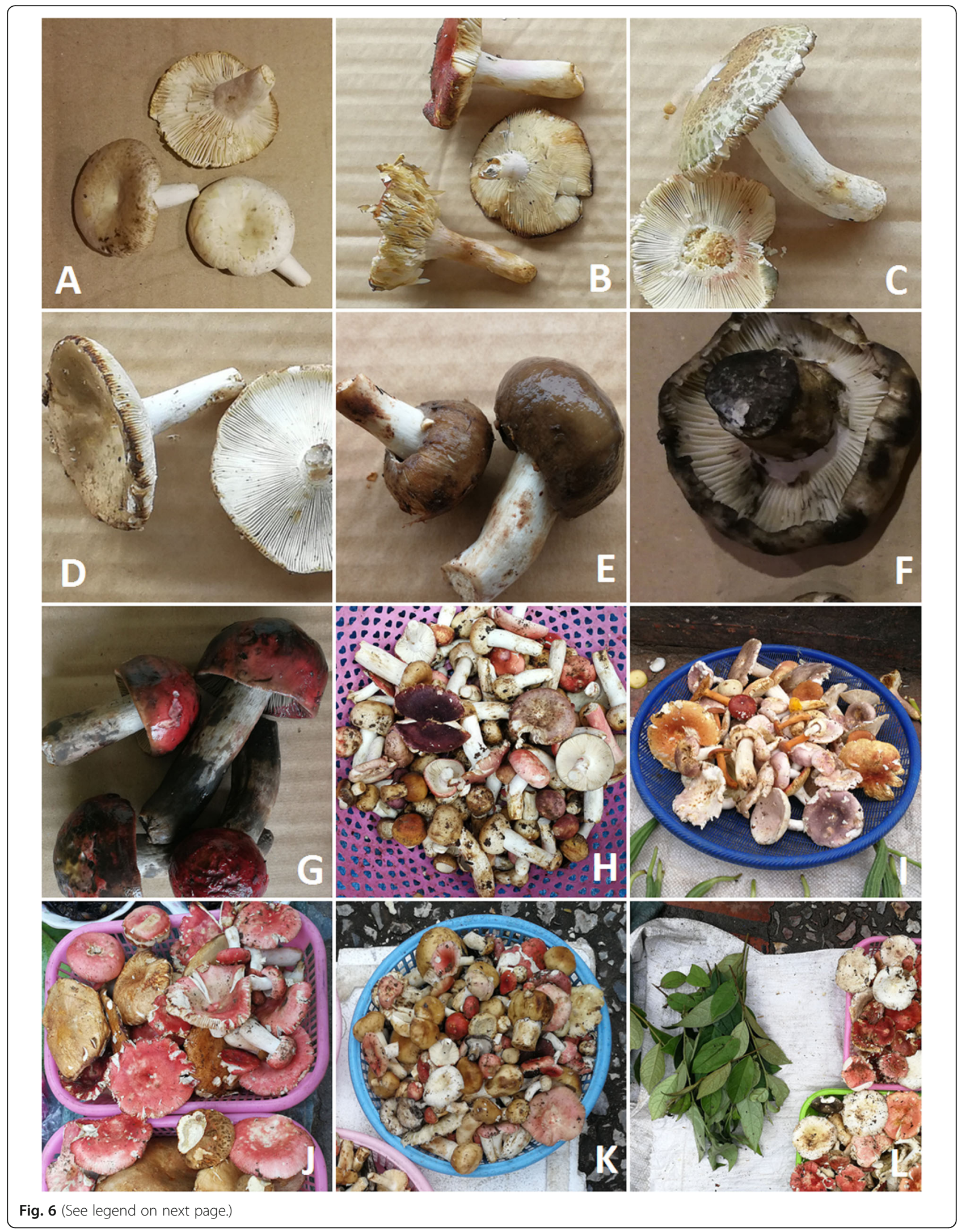


(See figure on previous page.)

Fig. 6 The diversity of brittlegills (Russula) sold in the studied markets (voucher numbers are given in brackets). Some of the unidentified specimens may be species unknown to science. a Russula alboareolata (WA0000072251). b Russula sp., (72252). c R. virescens (72253). d Russula sp. (72254). e Russula sp. (72258). f Russula sp. (72268). g R. paludosa (72270). h-k Russula species are usually sold mixed. I Antidesma acidum is only sold alongside Russula spp., as it is a special sour herb used the preparation of dishes made with Russula species

(predominantly annuals and biennials) dominate among currently used wild vegetables. The Mediterranean and many parts of China are examples of such places. However, in more wooded areas with a high level of biodiversity, local populations preserve the knowledge about the edibility of local, indigenous woody plants. This is the case in the Qingling Mountains in Shaanxi, China, where-similarly to Lao PDR-young shoots of many species of local trees and shrubs are used for food [99].

Even though we recorded much higher numbers of wild plants and fungi than in any other previous study from Southeast Asia, we suspect that even more species may still occasionally appear due to the extreme diversity of ingredients used by the population of Lao PDR. We hope this is only the beginning of a more detailed surveillance of Lao markets. This also applies to animals, which, as has been pointed out by Greatorex et al. [72], are a potential epidemiological hazard, as proven by the recent coronavirus epidemic [100].

The on going process of modernization of Lao society may bring a decrease in the number of taxa used. In some cases (protected animals), this may be with benefit to nature. In the case of plants and fungi, the taxa for sale are common species originating from rice fields, gardens, and nearby forests, exploited to a level which does not endanger them. Forgetting them may bring large loss to the rich Lao culinary tradition. Fortunately, all the ingredients listed in the Phia Sing's recipe book of the Lao royal court in Luang Prabang (including all the species of fungi) can still be found in markets, which demonstrate Lao cuisine's great resistance to change. We did detect some identification mistakes in Phia Sing's book: the plant listed as mak deed is not Ardisia crispa, but Solanum spirale Roxb., phak tam ling/phak tam nin listed as Melothria heterophylla is actually Coccinia grandis (L.)Voigt.

The large knowledge of forest products in Lao PDR can also serve as a model for tropical organic and permaculture movements, which advocate an increase in the number of food taxa we utilize with a minimal impact on nature [101]. However, this should be done without over-harvesting natural resources. Unfortunately, with the increasing population of Southeast Asia and the culinary popularity of "bush food", there is a danger that many species will become decimated [100]. Fortunately, our study found that it is mainly common weeds and semi-cultivated common tropical trees that are used as food sources, while the danger of overharvesting fungi is very unlikely and usually does not impact mushroom populations [102].

We hope that our study will add to the knowledge of edible fungi in SE Asia and help to distinguish them from the toxic taxa. This especially concerns the genus Amanita. There are many cases of fungi poisoning in Lao PDR. The recently published first atlas of Lao fungi [82] aims to help collectors, but many of the photographed taxa are only identified to the genus level and marked with numbers-this shows the vast need to perform mycotaxonomic and ethnomycological studies in Lao PDR.

The availability of the lists of wild food plants used in particular areas, especially those sold in markets, is very important both on a local and on a global scale. Such research on local food items allows for the recording of traditional products. Their exact taxonomic identification will make further phytochemical and nutritional research easier and enable the charcaterization of local food culture, which if properly advertized, can highly improve the livelihoods of local populations through international marketing and increasing these products' prices. The lists of plants used can also help increase existing local efforts to popularize Lao cuisine among tourists online [103] and via small ethnobotanical market guidebooks [104]. Moreover, it enables the detection of protected species sold in the markets. On a global scale, the inventorying of all wild foods is an important task for developing further strategies for improving the nutrition of the human population and food security [31, 94, 105-108].

\section{Conclusions}

The markets of Luang Prabang are very rich in wild edible plants, especially in wild vegetables originating from woody species. The list of fungi sold in them is the longest ever recorded in Asia. The incredible biological diversity we found there has urged us to make similar documentation in other large market towns of Lao PDR.

\section{Authors' contributions \\ The first author conceived the study and took part in all the field visits and interviews. KP and VL identified the plants. MP and MK identified the fungi. Other authors took part in some of the interviews and manuscript preparation. The authors read and approved the final version of the paper.}

\section{Funding}

The research was financed by the University of Rzeszów and private funds of the first author, as well as the Institute of Dendrology (Polish Academy of Sciences). 


\section{Availability of data and materials}

For voucher specimens, see "Methods" section.

\section{Ethics approval and consent to participate}

The research adhered to the local traditions for such research, the Code of Ethics of the International Society of Ethnobiology [109]. Prior oral informed consent was obtained from all study participants. Copies of voucher specimens were transferred to Poland with the Material Transfer Agreement received from the authorities of Lao PDR. The research was carried out in close cooperation with the Ministry of Science and Technology of Lao People's Democratic Republic and the regional authorities of Luang Prabang.

\section{Competing interests}

The authors declare that they have no competing interests.

\section{Author details}

${ }^{1}$ Institute of Biology and Biotechnology, ul. Pigonia 1, 35-310 Rzeszów, Poland. ${ }^{2}$ Department of Biology, Faculty of Natural Sciences, National University of Laos, Vientiane, Lao People's Democratic Republic. ${ }^{3}$ Pha Tad Ke Botanical Garden, Ban Wat That, PO Box 959, 06000 Luang Prabang, Lao People's Democratic Republic. ${ }^{4}$ Biotechnology and Ecology Institute, Ministry of Science and Technology, Doon Teaw Village, Km 14 Office, Thangon Road, Xaythany DistrictPO Box 2279, Vientiane, Lao People's Democratic Republic. ${ }^{5}$ Department of Science, Ministry of Science and Technology, Doon Teaw, Km 14, Thangon Road, Xaythany DistrictPO Box 2279, Vientiane, Lao People's Democratic Republic. ${ }^{6}$ Department of Science and Technology, Luang Prabang, Lao People's Democratic Republic. 'Institute of Dendrology, Polish Academy of Sciences, Parkowa 5, 62-035 Kórnik, Poland.

Received: 11 June 2020 Accepted: 28 October 2020

Published online: 26 January 2021

\section{References}

1. Bye RA. Medicinal Plants of the Sierra Madre: Comparative Study of Tarahumara and Mexican Market Plants. Econ Bot. 1986;40(1):103-24.

2. Nguyen ML, Doherty KT, Wieting J. Market survey research: a model for ethnobotanical education. Ethnobot Res Appl. 2008;17(6):087-92.

3. Mati $\mathrm{E}$, de Boer H. Ethnobotany and trade of medicinal plants in the Qaysari Market, Kurdish Autonomous Region. Iraq. J Ethnopharmacol. 2011;133(2); 490-510.

4. Sucholas J. Zioła i rośliny świąteczne miejskiego targowiska w Poznaniu (Wielkopolska): powrót do badań Szulczewskiego po 80 latach. Herbs and ceremonial plants of the urban marketplace in Poznan (Greater Poland): Szulczewski's study revisited after 80 years. Etnobiologia Polska. 2016;6:7-30.

5. Bussmann RW, Paniagua Z, Narel Y, Sikharulidze S, Kikvidze Z, Kikodze D, Tchelidze D, Batsatsashvili K, Robbie E. Plants in the spa-the medicinal plant market of Borjomi, Sakartvelo (Republic of Georgia), Caucasus. Indian J Tradit Know. 2017;16:25-34

6. Karousou R, Deirmentzoglou S. The herbal market of Cyprus: Traditional links and cultural exchanges. J Ethnopharmacol. 2011;133:191-203.

7. Hanlidou E, Karousou R, Kleftoyanni V, Kokkini S. The herbal market of Thessaloniki (N Greece) and its relation to the ethnobotanical tradition. J Ethnopharmacol. 2004;91:281-99.

8. Łuczaj Ł, Zovko-Končić M, Miličević T, Dolina K, Pandža M. Wild vegetable mixes sold in the markets of Dalmatia (southern Croatia). J Ethnobiol Ethnomed. 2013:9:2

9. Ertug F. Wild Edible Plants of the Bodrum Area (Mugla, Turkey). Turk J Bot. 2004;28:161-74.

10. Dogan Y, Ugulu I, Durkan N. Wild edible plants sold in the local markets of Izmir. Turkey. Pak J Bot. 2013;45(S1):177-84.

11. Nedelcheva A, Dogan Y. An ethnobotanical study on wild medicinal plants sold in the local markets at both sides of the Bulgarian-Turkish border. Planta Med. 2015;2015:81(16)

12. Dogan $Y$, Nedelcheva A. Wild plants from open markets on both sides of the Bulgarian-Turkish border. Ind J Trad Know. 2015;14(3):351-8.

13. Pemberton RW, Lee NS. Wild food plants in South Korea; Market presence, new crops, and exports to the United States. Econ Bot. 1996:50(1):57-70.

14. Xu YK, Tao GD, Liu HM, Yan KL, Dao XS. Wild vegetable resources and market survey in Xishuangbanna southwest China. Econ Bot. 2004;58(4): 647-67.
15. Shirai Y, Rambo AT. Urban Demand for Wild Foods in Northeast Thailand: A survey of edible wild species sold in the Khon Kaen municipal market. Ethnobot Res Appl. 2014;12:113-29.

16. Konsam S, Thongam B, Handique AK. Assessment of wild leafy vegetables traditionally consumed by the ethnic communities of Manipur, northeast India. J Ethnobiol Ethnomed. 2016;12:1.

17. Vlkova M, Verner V, Kandakov A, Polesny Z, Karabaev N, Pawera L, Nadvornikowa I, Banout J. Edible plants sold on marginal rural markets in Fergana Valley, southern Kyrgyzstan. Bulg J Agricult Sci. 2015;21(2):243-50.

18. Hamayun M, Khan MA, Begum S. Marketing of medicinal plants of UtrorGabral Valleys, Swat, Pakistan. Ethnobot Leaflets. 2003;2003(1):13.

19. Amiri MS, Joharchi MR. Ethnobotanical investigation of traditional medicinal plants commercialized in the markets of Mashhad, Iran. Avicenna J Phytomed. 2013;3:254-71.

20. Kumar $V$, Jain SK. Plant products in some tribal markets of central India. Econ Bot. 2002;56(3):242-5

21. Li DL, Zheng XL, Duan L, Deng SW, Ye W, Wang AH, Xing FW. Ethnobotanical survey of herbal tea plants from the traditional markets in Chaoshan, China. J Ethnopharmacol. 2017:205:195-206.

22. Silalahi M, Walujo EB, Supriatna J, Mangunwardoyo W. The local knowledge of medicinal plants trader and diversity of medicinal plants in the Kabanjahe traditional market, North Sumatra, Indonesia. J Ethnopharmacol. 2015;175:432-43.

23. Kosaka Y, Xayvongsa L, Vilayphone A, Chanthavong H, Takeda S, Kato M. Wild edible herbs in paddy fields and their sale in a mixture in Houaphan Province, the Lao People's Democratic Republic. Econ Bot. 2013;67(4):33549

24. Nguyen TS, Xia NH, Van Chu T, Van Sam H. Ethnobotanical study on medicinal plants in traditional markets of Son La province, Vietnam. Forest Soc. 2019:3(2):171-92.

25. Kar A, Borthakur SK. Wild vegetables sold in local markets of Karbi Anglong, Assam. Indian J Tradit Knowl. 2007;6(1):169-72.

26. Salam S, Jamir NS, Singh PK. Wild leafy vegetables sold in local markets of Ukhrul District of Manipur, India. Pleione. 2012;6(2):298-303.

27. Zhang L, Zhuang H, Zhang Y, Wang L, Zhang Y, Geng Y, Gou Y, Pei S, Wang Y. Plants for health: An ethnobotanical 25-year repeat survey of traditional medicine sold in a major marketplace in North-west Yunnan, China. J Ethnopharmacol. 2018;224:119-25.

28. Martin G. Searching for plants in peasant market-places. In: Plotkin MJ, Famolare $\mathrm{L}$, editors. Sustainable harvest and marketing of rainforest products. Washington, DC: Island Press, Washington; 1992. p. 212-23.

29. Cruz-Garcia G, Lagunez-Rivera L, Chavez-Angeles MG, Solano-Gomez R. The Wild Orchid Trade in a Mexican Local Market: Diversity and Economics. Econ Bot. 2015;69(4):291-305.

30. Boa E. Wild edible fungi: a global overview of their use and importance to people. Non-wood forest products 17. Rome: FAO; 2004.

31. Kasper-Pakosz $R$, Pietras $M$, Łuczaj $Ł$. Wild and native plants and mushrooms sold in the open-air markets of south-eastern Poland. J Ethnobiol Ethnomed. 2016;12(1):45.

32. Liu D, Cheng H, Bussmann RW, Guo Z, Liu B, Long C. An ethnobotanical survey of edible fungi in Chuxiong City, Yunnan, China. J Ethnobiol Ethnomed. 2018;14(1):42.

33. Sulaini AA, Sabran SF. Edible and medicinal plants sold at selected local markets in Batu Pahat, Johor, Malaysia. InAIP Conference Proceedings. 2018; 2002(1):020006 https://doi.org/10.1063/1.5050102 AlP Publishing. Accessed 3 Oct 2020

34. de Albuquerque UP, Monteiro JM, Ramos MA, de Amorim EL. Medicinal and magic plants from a public market in northeastern Brazil. J Ethnopharmacol. 2007:110(1):76-91.

35. Macía MJ, García E, Vidaurre PJ. An ethnobotanical survey of medicinal plants commercialized in the markets of La Paz and El Alto, Bolivia. J Ethnopharmacol. 2005:97(2):337-50.

36. Van Andel T, Myren B, Van Onselen S. Ghana's herbal market. J Ethnopharmacol. 2012;140(2):368-78.

37. Kool A, de Boer HJ, Krüger $\AA$, Rydberg A, Abbad A, Björk L, Martin G. Molecular identification of commercialized medicinal plants in Southern Morocco. PLoS One. 2012;7(6):e39459.

38. Penzes A. Budapesti viragok. Kerteszeti Lapok. 1926a;8:113-4.

39. Penzes A. Budapesti viragok. Kerteszeti Lapok. 1926b;9:130-1.

40. Muszyński. Wileńskie zioła ludowe. Wiadomości Farmaceutyczne. 1927;21-22: 469-76. 
41. Szulczewski JW. Grzyby sprzedawane na targach Poznania. Rocznik Nauk Rolniczych i Leśnych. 1933;29:1-12.

42. Szulczewski JW. O handlu roślinami leczniczemi na targach w Poznaniu. Poznań: Wydawnictwo Okręgowego Komitetu Ochrony Przyrody w Poznaniu; 1935. p. 80-7.

43. Dénes A. Wild plants for sale in the markets of Pécs then and now (Baranya, Hungary). Acta Ethnogr Hungarica. 2017;62(2):339-71.

44. Esguerra, et al. Purchasing Patterns and Consumer Level Waste of Fruits and Vegetables in Urban and Peri-Urban Centers in the Philippines. Food Nutr Sci. 2017;10(8):79890.

45. Batt PJ, Concepcion SB, Lopez MT, Axalan JT, Hualda LA, Montiflor MO. Exploring the institutional market for fresh vegetables in the Southern Philippines. In: III International Symposium on Improving the Performance of Supply Chains in the Transitional Economies, vol. 895; 2010. p. 59-68.

46. Davis WG. Social Relations in a Philippine Market: Self-interest and Subjectivity. Berkeley: University of California; 1973.

47. Franco FM, Chaw LL, Bakar N, Abas SN. Socialising over fruits and vegetables: the biocultural importance of an open-air market in Bandar Seri Begawan, Brunei Darussalam. J Ethnobiol Ethnomed. 2020;16(1):6.

48. Wendell, et al. Assessing lead concentrations in leafy evegetables in selected private markets in Metro Manila, Philippines. J Appl Technol Environ Sanit. 2012;3(2):175-8.

49. Chau HL, Thong HT, Chao NV, Hung PH, Hai W, An LV, Fujieda A, Ueru T, Akamatsu M. Microbial and parasitic contamination on fresh vegetables sold in traditional markets in Hue City, Vietnam. J Food Nutr Res. 2014;2(12):959-64.

50. Punsawad C, Phasuk N, Thongtup K, Nagavirochana S, Viriyavejakul P. Prevalence of parasitic contamination of raw vegetables in Nakhon $\mathrm{Si}$ Thammarat province, southern Thailand. BMC Public Health. 2019;19(1):34.

51. Chrun R, Hosotani Y, Kawasaki S, Inatsu Y. Microbioligical hazard contamination in fermented vegetables sold in local markets in Cambodia. Biocontrol Sci. 2017;22(3):181-5

52. Matsunaga $H$, Yokota $M$, Leakhena M, Sophany S. Collaborative exploration of Solanaceae vegetable genetic resources in southern Cambodia, 2017. Ann Rep Explor Introd Plant Genet Res. 2018;34:102-17.

53. Sugita T, Matsunaga H, Theavy S, Sophany S. Collaborative exploration of Capsicum genetic resources in northern Cambodia, 2016. Ann Rep Explor Introd Plant Genet Res. 2017;33:207-22.

54. Okuizumi H, Vilayheuang K, Hongphakdy K, Phengphachanh B, Noguchi T, Nonaka E, Intabon K, Yamamoto S. Collaborative Exploration for Millets Genetic Resources in Laos, October, 2014. Ann Rep Explor Introd Plant Genet Res. 2015;31:151-67.

55. Yamamoto SI, Hmwe NH, Deuanhaksa C, Kyaw MT, Suthiluk P, Watanabe K. Preliminary field survey of cultivated crops in north eastern Myanmar, northern Laos and northern Thailand, 2013. In: Annual Report on Exploration and Introduction of Plant Genetic Resources (NIAS, Tsukuba); 2015. p. 31.

56. Okuizumi H, Nonaka E, HonhphakdyK PB, Inagaki S. Collaborative exploration and collection of plant genetic resources in Laos, October 2015, vol. 2; 2016. p. L5. https://www.gene.affrc.go.jp/pdf/publications/plant-exp_2 015(32)_p215.pdf.

57. Cui X, Li W, Wei J, Qi Y, Li R, Yang Y, Shi Y, Meng X, Mi Y, Huot T, Sun W. Assessing the Identity of Commercial Herbs From a Cambodian Market Using DNA Barcoding. Front Pharmacol. 2020;11:244.

58. Lamxay V, de Boer HJ, Björk L. Traditions and plant use during pregnancy, childbirth and postpartum recovery by the Kry ethnic group in Lao PDR. J Ethnobiol Ethnomed. 2011;7(1):14.

59. de Boer HJ, Lamxay V, Björk L. Comparing medicinal plant knowledge using similarity indices: a case of the Brou, Saek and Kry in Lao PDR. J Ethnopharmacol. 2012;141(1):481-500.

60. Soejarto DD, Gyllenhaal C, Kadushin MR, Southavong B, Sydara K, Bouamanivong S, Xaiveu M, Zhang HJ, Franzblau SG, Tan GT, Pezzuto JM. An ethnobotanical survey of medicinal plants of Laos toward the discovery of bioactive compounds as potential candidates for pharmaceutical development. Pharm Biol. 2012;50(1):42-60.

61. Libman AS. Medical ethnobotany of Laos. Berkeley: University of Illinois at Chicago, Health Sciences Center; 2006.

62. NAFRI, NUoL. SNV: Non-Timber Forest Products in the Lao PDR, A Manual of 100 Commercial and Traditional Products. Vientiane: The National Agriculture and Forestry Research Institute; 2007.

63. Pedersen OS, Thammavong K. Biodiversity: Wild Mushrooms - Edible and Medicinal Species: Local Knowledge and Use. Pilot Survey. Bong, Mixay, Yai,
Lethong, Gnordphe and Poua-Xai villages, Phoukhout District, Xieng Khouang Province. Lao PDR. Laos: Agro-biodiversity Project.

64. Jensen A, Meilby H. Returns from Harvesting a Commercial Non-timber Forest Product and Particular Characteristics of Harvesters and Their Strategies: Aquilaria crassna and Agarwood in Lao PDR. Econ Bot. 2010; 64(1):34-45.

65. Yamada K, Yanagisawa M, Kono Y, Nawata E. Use of Natural Biological Resources and Their Roles in Household Food Security in Northwest Laos. Southeast Asian Studies. 2004:41:426-43.

66. Whitney CM, Min VS, Giang LH, Can W, Lanh TT, Barber K. Conservation and Ethnobotanical Knowledge of a Hmong Community in Long Lan, Luang Prabang, Lao People's Democratic Republic. Ethnobot Res Appl. 2014;12: 643-58.

67. Vongkhamsao $V$. The importance, role and value of Non -Wood Forest Product forLaotian food Security, nutrition and livelihoods. Vientiane: National Agriculture and Forestry Research Institute; 2006.

68. Foppes J, Ketphanh S. NWFP use and household food security in the Lao PDR. Symposium Biodiversity Food Security. 2004;14.

69. Dubost JM, Lamxay V, Krief S, Falshaw M, Manithip C, Deharo E. From plant selection by elephants to human and veterinary pharmacopeia of mahouts in Laos. J Ethnopharmacol. 2019;244:112157.

70. Suzuki D, Fuse K, Aizu M, Yoshizawa S, Tanaka W, Araya K, Praxaysombath B. Reptile diversity in food markets in Laos. Current Herpetology. 2015;34(2): $112-9$.

71. Nooren $\mathrm{H}$, Claridge G. Wildlife trade in Laos: the End of the Game. Netherlands Committee 183 for IUCN. Amsterdam: IUCN; 2001.

72. Greatorex ZF, Olson SH, Singhalath S, Silithammavong S, Khammavong K, Fine AE, Weisman W, Douangngeun B, Theppangna W, Keatts L, Gilbert M. Wildlife trade and human health in Lao PDR: an assessment of the zoonotic disease risk in markets. PLoS One. 2016:11(3):e0150666.

73. Schweikhard J, Kasper K, Ebert CL, Lehmann M, Erbe P, Ziegler T. Investigations into the illegal wildlife trade in central Lao PDR. TRAFFIC Bulletin. 2019;31(1):19.

74. Barennes H, Phimmasane M, Rajaonarivo C. Insect Consumption to Address Undernutrition, a National Survey on the Prevalence of Insect Consumption among Adults and Vendors in Laos. PLoS One. 2015;10(8):e0136458.

75. Newman MF. Impatiens pachycaulon (Balsaminaceae), a new species from Laos. Edinburgh J Bot. 2008;65:23-6.

76. Jenkins PD, Kilpatrick CW, Robinson MF, Timmins RJ. Morphological and molecular investigations of a new family, genus and species of rodent (Mammalia: Rodentia: Hystricognatha) from Lao PDR. Syst and Biodivers. 2005:2(4):419-54.

77. $\quad$ Sing P. Traditional recipes of Laos. UK: Prospect Books; 1981.

78. Vidal J. Les Plantes utiles du Laos (suite). J d'agriculture tropicale et de botanique appliquée. 1959:6(11):589-94.

79. Vidal J. Les Plantes utiles du Laos (suite). J d'agriculture tropicale et de botanique appliquée. 1961:8(8-9):356-85.

80. Vidal J. Les Plantes utiles du Laos. J d'agriculture tropicale et de botanique appliquée. 1959:6(8-9):391-404.

81. Mortimer PE, Xu J, Karunarathna SC, Hyde KD. Mushrooms for Trees and People: A field guide to useful mushrooms of the Mekong region. Kunming: World Agroforestry Centre; 2014.

82. Laessoe T, Pedersen OS, Sysouphantong P. An Introduction to the Edible, Poisonous and Medicinal Fungi of Northern Laos. Vientiane: No publisher given; 2019.

83. Newman M, Ketphanh S, Svengsuksa B, Thomas P, Sengdala K, Lamxay V, Armstrong K. A checklist of the vascular plants of Lao PDR. Edinburgh: Royal Botanic Garden Edinburgh; 2007.

84. Greatorex ZF, Olson SH, Singhalath S, Silithammavong S, Khammavong K, Fine AE, Weisman W, Douangngeun B, Theppangna W, Keatts L, Gilbert M, Karesh WB, Hansel T, Inthakoun L, Delang CO. Lao Flora A checklist of plants found in Lao PDR with scientific and vernacular names. Morrisville: Lulu Press; 2008

85. Schoch $\mathrm{CL}$, et al. Nuclear ribosomal internal transcribed spacer (ITS) region as a universal DNA barcode marker for fungi. Proc Natl Acad Sci. 2012; 109(16):6241-6.

86. Schidnel DE, Miller SE. DNA barcoding a useful tool for taxonomists. Nature. 2005:435(7038):17-8

87. Eberhardt U. Methods for DNA barcoding of fungi. In: DNA barcodes. Totowa: Humana Press; 2012. p. 183-205.

88. GenBank. http://www.ncbi.nlm.nih.gov/. Accessed 1 Mar 2020. 
89. Nilsson RH, Larsson K-H, Taylor AFS, Bengtsson-Palme J, Jeppesen TS, Schigel D, Kennedy P, Picard K, Glöckner FO, Tedersoo L, Saar I, Köljalg U, Abarenkov K. The UNITE database for molecular identification of fungi: handling dark taxa and parallel taxonomic classifications. Nucleic Acids Res. 2018; https://doi.org/10.1093/nar/gky1022.

90. The Plant List: a working list of all plant species. http://www.theplantlist. org/. Accessed 10 Mar 2020.

91. Index Fungorum. http://www.indexfungorum.org/. Accessed 10 Mar 2020

92. Deur D, Turner NJ, editors. Keeping it living: traditions of plant use and cultivation on the Northwest Coast of North America. Seattle: University of Washington Press; 2005

93. Söukand R, Kalle R. Emic conceptualizaion of a 'wild edible plant' in Estonia in the second half of the $20^{\text {th }}$ century. TRAMES - J Humanities Soc Sci. 2015; 19(1):15-34

94. Nanagulyan S, Zakaryan N, Kartashyan N, Piwowarczyk R, Łuczaj Ł. Wild plants and fungi sold in the markets of Yerevan (Armenia). J Ethnobiol Ethnomed. 2020;16:26.

95. Pérez-Moreno J, Martínez-Reyes M, Yescas-Pérez A, Delgado-Alvarado A, Xoconostle-Cázares B. Wild mushroom markets in central Mexico and a case study at Ozumba. Econ Bot. 2008;62(3):425-36.

96. Montoya-Esquivel A, Estrada-Torres A, Kong A, Juárez-Sánchez L. Commercialization of wild mushrooms during market days of Tlaxcala, Mexico. Micologia Aplicada Int. 2001;13(1):31-40

97. Huai HY, Zhang B, Liu HS. Ethnobotany of wild edible plant resources in periodic markets in jinping autonomous county of Miao, Yao, and Dai. Acta Botanica Yunnanica. 2008;30(5):603-10.

98. Zhang Y, Li JW, San MM, Whitney CW, San TT, Yang XF, Mon AM, Hein PP. The Secret of Health in the Daily Cuisine: the Typical Health Vegetables in the Local Markets in Central Myanmar. J Ethnobiol Ethnomed. 2020; 16:73.

99. Kang Y, Luczaj L, Ye S, Zhang S, Kang J. Wild food plants and wild edible fungi of Heihe valley (Qinling Mountains, Shaanxi, central China): herbophilia and indifference to fruits and mushrooms. Acta Soc Bot Pol. 2012;81(4):239-44.

100. Volpato G, Fontefrancesco MF, Gruppuso P, Zocchi DM, Pieroni A. Baby pangolins on my plate: possible lessons to learn from the COVID-19 pandemic. J Ethnobiol Ethnomed. 2020;16.

101. Jose S. Agroforestry for conserving and enhancing biodiversity. Agrofor Sys. 2012;85(1):1-8.

102. Egli S, Peter M, Buser C, Stahel W, Ayer F. Mushroom picking does not impair future harvests-results of a long-term study in Switzerland. Biol Conserv. 2006;129(2):271-6.

103. Pha Khao Lao. https://www.phakhaolao.la Accessed 1 Oct 2020

104. Vongsouline S. What's in the market? A Visitor's Guide to Lao Tastes, Culture and Daily Life. Luang Prabang: Big Brother Mouse; 2010.

105. Gahukar RT. Potential of minor food crops and wild plants for nutritional security in the developing world. J Agr Food Inform. 2014;15(4):342-52.

106. Pieroni A, Hovsepyan R, Manduzai AK, Sõukand R. Wild food plants traditionally gathered in central Armenia: archaic ingredients or future sustainable foods? Environ Dev Sustain. 2020;13:1-24.

107. Soukand R, Stryamets N, Fontefrancesco MF, Pieroni A. The importance of tolerating interstices: Babushka markets in Ukraine and Eastern Europe and their role in maintaining local food knowledge and diversity. Heliyon. 2020; 6(1):e03222.

108. Pawera L, Khomsan A, Zuhud EA, Hunter D, Ickowitz A, Polesny Z. Wild Food Plants and Trends in Their Use: From Knowledge and Perceptions to Drivers of Change in West Sumatra, Indonesia. Foods. 2020;9(9):1240.

109. International Society of Ethnobiology Code of Ethics (with 2008 additions). http://ethnobiology.net/code-of-ethics/. Accessed 10 Mar 2016.

\section{Publisher's Note}

Springer Nature remains neutral with regard to jurisdictional claims in published maps and institutional affiliations.

Ready to submit your research? Choose BMC and benefit from:

- fast, convenient online submission

- thorough peer review by experienced researchers in your field

- rapid publication on acceptance

- support for research data, including large and complex data types

- gold Open Access which fosters wider collaboration and increased citations

- maximum visibility for your research: over $100 \mathrm{M}$ website views per year

At BMC, research is always in progress.

Learn more biomedcentral.com/submissions 